\title{
Use of necrophagous insects as evidence of cadaver relocation: myth or reality?
}

\author{
Damien Charabidze ${ }^{\text {Corresp., }}{ }^{1}$, Matthias Gosselin ${ }^{2}$, Valéry Hedouin ${ }^{1}$ \\ ${ }^{1}$ CHU Lille, EA 7367 - UTML - Unite de Taphonomie Medico-Legale, Univ Lille, Lille, France \\ 2 Research Institute of Biosciences, Laboratory of Zoology, UMONS - Université de Mons, Mons, Belgium \\ Corresponding Author: Damien Charabidze \\ Email address: damien.charabidze@univ-lille2.fr
}

The use of insects as indicators of post-mortem displacement is discussed in many texts, courses and TV shows, and several studies addressing this issue have been published. Although the concept is widely cited, it is poorly understood, and only a few forensic cases have successfully applied such a method. The use of necrophagous insects as evidence of cadaver relocation involves a wide range of biological aspects. Distribution, microhabitat, phenology, behavioral ecology and molecular analysis are among the research areas associated with this topic. This article provides the first review of the current knowledge on this topic and addresses the potential and limitations of different methods to evaluate their applicability. This work reveals numerous weaknesses and erroneous beliefs as well as many possibilities and research opportunities. 
1 Use of necrophagous insects as evidence of cadaver relocation: myth or reality?

2

3 Damien Charabidze ${ }^{1}$, Matthias Gosselin ${ }^{2}$, Valery Hedouin ${ }^{1}$

4

$5 \quad{ }^{1}$ CHU Lille, EA 7367 - UTML - Unite de Taphonomie Medico-Legale, Univ Lille, Lille, France

$6{ }^{2}$ Research Institute of Biosciences, Laboratory of Zoology, UMONS - Université de Mons,

7 Mons, Belgium

8

9 Corresponding author:

10 Damien Charabidze

11 damien.charabidze@univ-lille2.fr 


\section{Abstract}

13 The use of insects as indicators of post-mortem displacement is discussed in many texts, courses

14 and TV shows, and several studies addressing this issue have been published. Although the

15 concept is widely cited, it is poorly understood, and only a few forensic cases have successfully

16 applied such a method. Surprisingly, the use of insects as indicators of post-mortem

17 displacement has never been addressed in a cross-disciplinary context. The use of necrophagous

18 insects as evidence of cadaver relocation involves a wide range of biological aspects.

19 Distribution, microhabitat, phenology, behavioral ecology and molecular analysis are among the

20 research areas associated with this topic. This article provides the first review of the current

21 knowledge on this topic and addresses the potential and limitations of different methods to

22 evaluate their applicability. This work reveals numerous weaknesses and erroneous beliefs as

23 well as many possibilities and research opportunities. 
24 List of contents

25 A. Introduction

26

27

28

29

30

31

32

33

\section{A.1 Context}

A.2 Survey methodology

B. Spatial separation

B.1 Biogeography of European species of forensic importance

B.2 Species-specific habitats

Indoor vs. outdoor

Open vs. forest and sunny vs. shaded places

Rural vs. urban

Other specific locations

Water

Insects of buried/concealed cadavers

B.3 Conclusions related to species-specific habitats

C. Behavior and development of instars

C.1 Adult behavior: colonization and egg laying

C.2 Larval development, wandering larvae and pupae

D. Phenology and colonization time

E. Contribution of molecular analyses

E.1 Cuticular hydrocarbons

E.2 Genetics of insect populations

E.3 Identification of human DNA 
47 G. References 


\section{A. Introduction}

49

50

51

52

53

54

55

56

57

58

59

60

61

62

63

64

65

66

67

68

69

\section{A.1 Context}

This article reviews the current knowledge and potential of different methods involving the use of insects to study cadaver relocation and evaluates their feasibilities.

Insect analysis has been used in legal investigations for decades in a practice now known as forensic entomology (Benecke, 2001). Increased interest in this field since the late 20th century has resulted in more frequent use of forensic entomology in investigations and the development of research on necrophagous species. Previous reviews have compiled and explained the aims and methods of forensic entomology (Catts \& Goff, 1992; Byrd \& Castner, 2009, Bala, 2015), but some fundamental questions remain unresolved, particularly the potential use of insects as evidence of corpse relocation.

Cadaver decomposition can be altered due to human activity, especially steps taken to hide a cadaver (Haglund \& Sorg, 1997). Attempts to prevent discovery include cadaver concealment, wrapping and displacement. Such post-mortem relocation can occur shortly after death or after days of concealment. It can occur over short (e.g., from the room where death occurred to the garden of the house) or long distances. In most cases, the location where the cadaver is hidden is very different from that where death occurred (Reibe et al., 2008). Currently, only a few scientific methods are available to determine whether a crime scene is a primary or secondary scene (Miller et al., 2005). Because the biology and ecology of necrophagous species can convey information on where and how insects live, forensic manuals and courses often state that insects can be used as evidence of cadaver relocation (Catts \& Goff, 1992; Byrd \& Castner, 2009; Smith, 1986; Joseph et al., 2011; Mozayani \& Noziglia, 2011; Archer \& Wallman, 2016; Payne \& Byard, 2015). However, while this idea is appealing, it may not reflect reality. 
72 geographic region different from that in which it is discovered, this is an indication that the body

73 may have been moved following death" (Mozayani \& Noziglia, 2011). However, most, if not all,

74 European necrophagous species have large distribution areas covering many countries and

75 hundreds of thousands of square kilometers, making the sampling of non-native species within

76 European regions unlikely. Furthermore, while each species has an ecological niche (e.g., forest

77 or synanthropic environment; sunny or shady habitats), individuals can sometimes occur outside

78 the preferred range. Additionally, the long dispersal capability of most necrophagous species,

79 notably blow flies, makes it difficult to relate a given species to a particular place or habitat and

80 thus draw inferences regarding cadaver relocation (Nazni et al., 2005; Bomphrey, Walker \&

81 Taylor, 2009, Zabala, Díaz \& Saloña-Bordas, 2014).

82

Temporal separation is another characteristic of necrophagous species. The phenology

83 (cyclic and seasonal phenomena) of blow flies is well known; some species are primarily active

84 during hot weather, whereas others are adapted to cold climates (Voss, Spafford \& Daddour,

85 2009). Under some circumstances, such seasonality might contribute useful information

86 regarding the chronology of cadaver decomposition. However, the presence of larvae of a

87 summer species on a cadaver discovered in the winter does not constitute indisputable evidence

88 of cadaver relocation. In addition, colonization time is strongly dependent on the stage of

89 decomposition. Although it is far more complex than squads (Wyss, Cherix \& Mangin, 2013),

90 succession on cadavers has been experimentally shown in several countries and under a variety

91 of conditions (Anderson \& Van Laerhoven, 1996; Abd El-Bar \& Sawaby, 2011; Abouzied, 2014;

92 Archer, 2014). Divergence from known succession patterns, such as the absence of certain

93 species or unusual associations, might indicate cadaver relocation or concealment. The presence 
94 or absence of some instars is also of relevance, especially with regard to wandering larvae or

95 pupae of pioneer species (e.g., Calliphoridae flies), which pupate away from the cadaver and can

96 thus be found after cadaver removal.

$97 \quad$ Advances in genetics also offer numerous opportunities. Genetic analyses allow the 98 assignment of individuals to local populations or even sub-populations. As noted by Tomberlin 99 et al. (2011), such analyses are of great interest in the context of cadaver relocation. In addition, 100 the genetic analysis of gut contents has potential for identifying the cadaver that larvae have been 101 feeding on (Campobasso et al., 2005; Calvignac-Spencer et al., 2013). This technique should be 102 developed in the coming years and provide new tools for forensic entomologists and crime scene 103 investigations.

104 This review analyses in details these different approaches. It reveals weaknesses and 105 mistaken beliefs regarding the use of forensic entomology as evidence of cadaver displacement 106 as well as many promising aspects and development opportunities.

The first phase of the survey involved identifying the magnitude of the issue of cadaver relocation. This phase was performed by searching the main forensic literature published in

111 English over the last 40 years for studies addressing corpse relocation. We found references to 112 this idea in several forensic entomology books and studies (Catts \& Goff, 1992; Byrd \& Castner, 113 2009; Smith, 1986; Joseph et al., 2011; Mozayani \& Noziglia, 2011; Archer \& Wallman, 2016; 114 Payne \& Byard, 2015) but few case reports (Goff, 1991; Benecke, 1998; Krikken \& Huijbregts, 115 2001). We also found several research articles addressing corpse relocation as a main goal or 116 claiming the potential application of their findings to this topic. From this dataset, we outlined 
117 various facets of the problem and gathered them into four main concepts: spatial separation,

118 behavior/development, phenology/colonization time and molecular analyses. We then searched

119 the literature within each of these fields for data on the potential use of different methods to

120 study corpse relocation. The resulting dataset was then analyzed to identify discrepancies or

121 methods with strong application potential.

122 Due to the number of factors that can affect insect occurrence on corpses (e.g., species, 123 climates, geography), we focus on the central European area. However, most of the conclusions 124 of this review can be generalized to other locations.

125

126

\section{B. Spatial separation}

Only a few hundred insect species are associated with cadavers, of which a few dozen are strictly necrophagous (requiring a cadaver to feed on during at least a part of their development) (Smith, 1986). Their diversity is apparent from their variability in size, shape, behavior,

ecological niche and distribution and reflects species-specific adaptations, which allow species to exploit different habitats and resources. Johnson defined four orders of habitat selection, ranging from large geographical areas to local microhabitats (Johnson, 1980). Furthermore, those that at least 1) have a strong preference for a given geographical area or habitat, 2) are resistant to relocation disturbance, 3) live on cadavers and 4) colonize cadavers shortly after death. Furthermore, common species are more likely to be found in association with criminal cases than are infrequent species. Unfortunately, an association with a specific habitat appears to

138 be more pronounced in less common species than in more common ones (MacLeod \& Donnelly, 139 1957). 


\section{B.1 Biogeography of European species of forensic importance}

142

143

144

145

146

147

148

149

150

151

152

153

154

155

156

157

158

159

160

161

162

According to the common definition, the distribution of a species is the geographical area within which that species is observed. Species may not be uniformly distributed in this area: variation in local density (e.g., a clumped distribution) is common. However, individuals of a given species are not often observed outside of their distribution area. Online interactive maps can now be found on the web for most European taxa. Many of these databases combine older distribution data and contemporary records from amateur or professional entomologists (Global Biodiversity Information Facility, 2017, www.gbif.org). Such collaborative work is subject to information gaps and biases, particularly a lack of records; as a result, species distribution maps reflect the distribution of specialists more than the distribution of species (Fig. 1). In particular, a lack of records affects necrophagous species, which are infrequently sought out and are poorly known among entomologists. As a result, a necrophagous species detected in previously unsampled site may be considered unusual/unexpected while in fact being well within the species' distribution.

To be informative in determining cadaver relocation, a necrophagous species must have a restricted and well-established distribution. We list here the few European necrophagous species meeting these criteria.

Two common species of the genus Cynomya have restricted distributions within Europe. C. mortuorum, a large, hairy bluebottle fly, can be found across the entire Palearctic region (Braet et al., 2015) (Fig. 1). But this species is rarely reported in central European countries, especially in a forensic context (Rognes, 1991; Starkeby, 2001; Dekeirsschieter et al., 2013; Wyss, Cherix \& Mangin, 2013; Braet et al., 2015). Its distribution partially overlaps that of $C$. 
163 cadaverina (Robineau-Desvoidy, 1830), another cold-adapted species of forensic interest 164 (Rognes, 1991; Kurahashi \& Kuranishi, 2000).

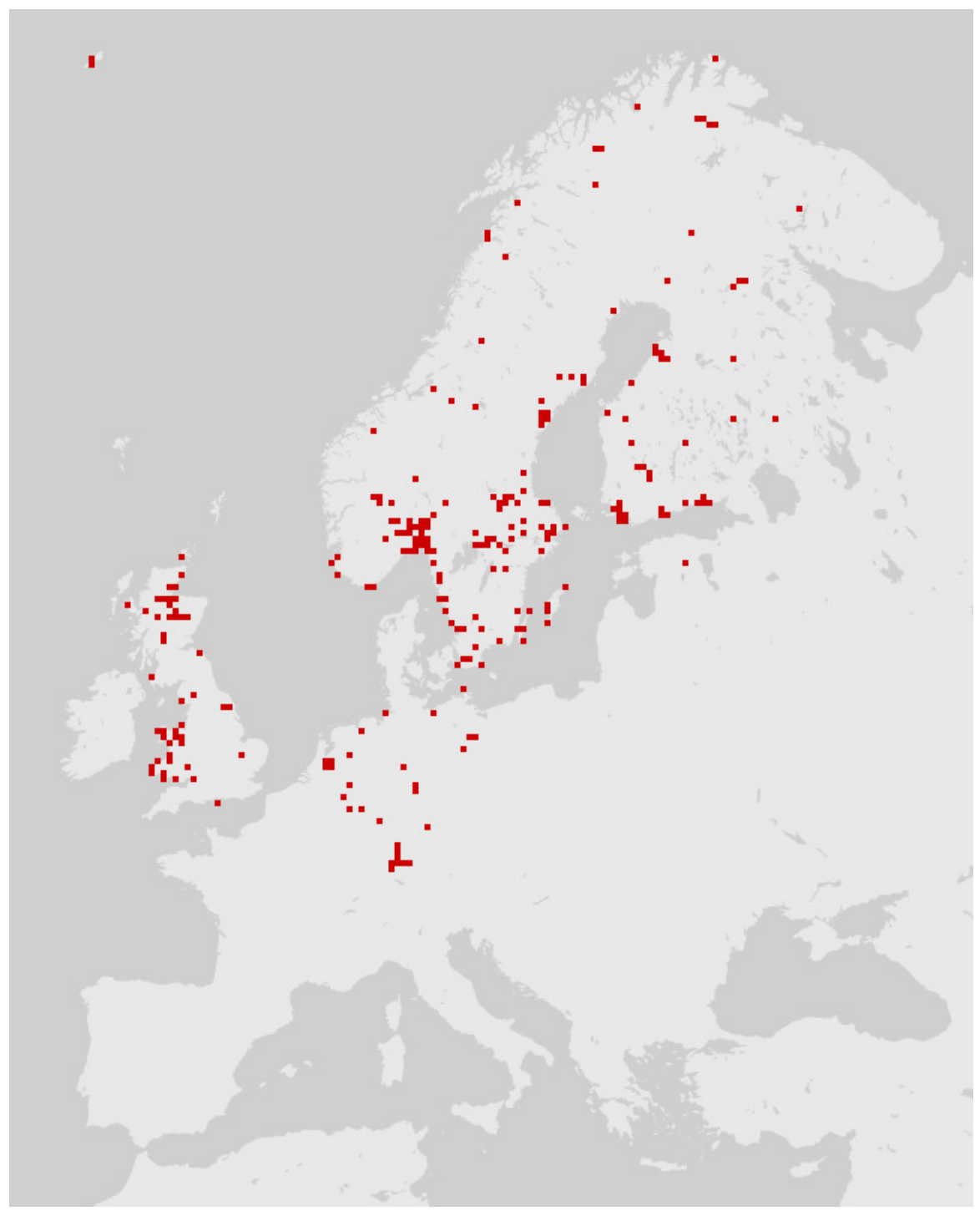

167 Figure 1. The distribution of Cynomya mortuorum in Europe (source: www.gbif.org, 09/2016).

168 Although not reflected in the above map or represented in the source database, this species is 169 present in northern France (Bourel et al., 1999), the mountains of central France and Italy 
170 (unpublished data). This map is truncated due to a lack of published/registered data rather than to 171 geographical restriction.

172

173

Two other calliphorid flies, Calliphora loewi and C. subalpina, show a sub-alpine

174 distribution (Faucherre, Cherix \& Wyss, 1999; Rognes, 1991). In Europe, C. loewi is mostly

175 found in northern and central Europe, from Siberia and the Caucasus to the Central European

176 Territories (Smith, 1986). Although this northern distribution area suggests this species might be

177 good indicator of relocation, its recent discovery in Madeira Island (Portugal) calls its relevance

178 into question (Prado e Castro et al., 2016). Furthermore, although it has a large distribution, $C$.

179 loewi is often recorded at low abundance, making sampling of this species on a relocated corpse

180 unlikely (Szpila et al., 2014). C. subalpina has a very similar distribution area and is subject to

181 similar limitations (Rognes, 1991).

182 Chrysomya albiceps is one of the few species that is theoretically usable as an indicator

183 of cadaver relocatin in Europe (Grassberger, Friedrich \& Reiter, 2003). The species is

184 meridional, common and abundant in southern Europe and in most of the Neotropical,

185 Afrotropical and Oriental regions (Grassberger, Friedrich \& Reiter, 2003). However, while it is

186 mostly found in southern Europe, Ch. albiceps has been observed migrating northward during

187 the hot summer months (Wyss, Cherix \& Mangin, 2013). This northward expansion of its range

188 has the potential to cause confusion and precludes its use as evidence of cadaver relocation.

189 Similar factors affect the use of Ch. megacephala, an Asian fly recently recorded in continental

190 Europe and extending its distribution into the Mediterranean region (Martinez-Sanchez, Marcos-

191 Garcia \& Rojo, 2001; Ebejer, 2007; Prado e Castro \& Garcia, 2010; Bao \& Wells, 2014). 
these species are unusual, difficult to identify and poorly documented. Thus, although they may

194 be informative, these insects cannot be regarded as true indicators of cadaver relocation

195 according to the criteria listed by Matuszewski, Szafalowicz \& Jarmusz (2013). According to

196 this review, to date, insect distribution area as an indicator of long-distance cadaver relocation

197 appears to be limited in application, with little utility for empirical forensics. However, the

198 distribution of C. mortuorum (Fig. 1) is a great example of an incomplete dataset that could be

199 easily enhanced by forensic case databases and natural history collections targeted on carrion

200 feeding insects. This example also highlights the potential of species distribution models based

201 on environmental niche modeling, e.g., Maximum Entropy Algorithm (MaxEnt) (Szyniszewska

202 \& Tatem, 2014; Ali Hanafi-Bojd et al., 2015; Kumar, Yee \& Neven, 2016). Such models can

203 provide probabilities of the locations of certain insects in a given area and could be used in a

204 forensic context to determine the likelihood of cadaver relocation.

205

206

\section{B.2 Species-specific habitats}

207

Many forensic cases involve cadavers that have been transported some kilometers from

the crime scene, especially to low-traffic areas such as forests, dumping sites, rivers or seashores

209 (secondary decomposition sites) (Matuszewski, Szafalowicz \& Jarmusz, 2013). As discussed

210 above, such short-distance relocation cannot be elucidated using the presence of foreign

211 necrophagous species. However, the transfer of a cadaver to a new location can alter micro-

212 environmental conditions such as climate, extent of synanthropy, vegetation conditions and

213 indoor/outdoor location. The population of necrophagous insects at the secondary decomposition

214 site may therefore differ from that of the initial (primary) environment. 
216 Turner, 2005; Brundage, Bros \& Honda, 2011). However, published data regarding species-

217 specific habitats vary, highlighting that such preferences are not fixed and often vary locally. The

218 biology of necrophagous species contributes to this variability. To successfully reproduce, adult

219 females must find suitable carrion for their offspring. However, the occurrence of cadavers is by

220 definition unpredictable because death is temporally and spatially random. Accordingly, all

221 necrophagous species have an efficient olfactory sense that allows individuals to quickly detect

222 and locate cadavers. As noted by MacLeod and Donnelly (1957), blow flies are powerful and

223 active flies capable of dispersing over large distances (several kilometers per day).

224

Furthermore, most studies in forensic entomology use simple descriptors (e.g., forest,

sunny, indoor) without taking into account the surroundings or variability within categories (e.g.,

forest type or city size). Additionally, larger-scale effects and interactions of parameters (e.g.,

227

228

229

230

231

232

233

234

235

236

237

temperature and city size) are typically not considered (Zabala, Díaz and Saloña-Bordas, 2014).

In a 1957 study, MacLeod and Donnelly stated that "there is nothing to indicate whether the nonuniform distribution of the adult (flies) population is due to the faunal, floral, vegetationstructural or edaphic element of the environment, or to some combination of these". More than fifty years later, Zabala, Díaz and Saloña-Bordas (2014) concluded that, except for the summer abundance of $C$. vomitoria, blow fly community composition could not be used as evidence of cadaver relocation, particularly in heterogeneous and densely populated areas. These authors also noted that conclusions based on species-specific habitat preferences should be drawn only on the basis of local studies (Davies, 1990; Anderson \& Van Laerhoven, 1996; Hwang \& Turner, 2005; Brundage, Bros \& Honda, 2011). The following sub-section focuses on specific habitat characteristics that may be of relevance in determining the primary deposition site of a cadaver. 
Indoors vs. outdoors

The question of the inside/outside location of a cadaver is a key point in many forensic

241 investigations (Frost et al., 2010). The location of a cadaver affects its colonization time (the pre-

242

243 appearance interval, i.e., the time before insects reach the cadaver) and thus the post-mortem interval estimation (Pohjoismaki et al., 2010; Reibe \& Madea, 2010; Charabidze, Hedouin \& 244 245 246 247 248 249 250 251 252 253 254

Gosset, 2015). Furthermore, access to the cadaver by necrophagous insects greatly affects its decomposition (MacLeod \& Donnelly, 1962; Campobasso, Di Vella \& Introna, 2001). An indoor location also protects the cadaver from rain and is often associated with higher temperatures, which can increase the development rate of the larvae.

The species associated with indoor locations have been investigated in many field studies and case reports. A pioneer study by Goff of 35 forensic entomology cases in Hawaii noted that more insect species were found indoors than outdoors (Goff, 1991). During winter experiments, Centeno, Maldonado and Oliva (2002) found two more species on carrions that were sheltered than on unsheltered ones. Anderson found the same species (except Lucilia illustris) on both inside and outside cadavers (Anderson, 2011). In contrast, Cainé et al. (2009) found more fly species on outdoor cadavers than on indoor cadavers in Portugal, and Reibe and Madea (2010) similarly found greater species diversity in outdoor locations. In the Reibe and Madea experiment, piglet carcasses located indoors (1st-floor room) were exclusively infested by $C$. vicina, whereas a variety of blow fly species (L. sericata, L. caesar, L. illustris, C. vicina and C. vomitoria) were found on the outdoor (garden) piglet carcasses. Cammack et al. (2016) recently published similar data on the decomposition of concealed and exposed porcine remains in North 
260 Carolina. According to this study, concealment had a significant effect on the insect community, 261 and colonization was delayed by $35-768 \mathrm{~h}$ depending on the degree of concealment.

262 The importance of cadaver location was also observed for larder beetles, which 263 preferentially feed and breed on dry material (Charabidze, Hedouin and Gosset, 2013). While 264 feeding larvae were more common in indoor forensic cases than in outdoor ones, no clear 265 preference was observed among adults. The same authors also found an effect of cadaver 266 location on the presence of $N$. littoralis (Charabidze et al., 2016). Leclercq reported Silphidae 267 species only from cadavers recovered from forest sites in Belgium (Dekeirsschieter et al., 2013), 268 and Dekeirsschieter et al. (2011) did not identify any Silphidae species in cadavers found in 269 urban Belgium. However, Chauvet and colleagues (2008) recorded the presence of Nicrophorus 270 spp. on human cadavers discovered inside houses in France.

271 In accordance with these discrepancies, Frost et al. (2010) noted that although more 272 species and specimens tend to be observed indoors than outdoors, this trend is not consistent. An 273 extensive table summarizing the insect species reported from human remains found indoors can 274 be found in their study (Frost et al., 2010). The authors note that "none of the(se) listed insect 275 species can be considered as exclusively indoors." An example of the difficulty in formally 276 associating the presence of a species to the inside/outside location is provided by Krikken and 277 Huijbregts (2001). From the numerous dead Lucicia adult flies (no species name was reported) 278 observed in an upstairs room with closed windows, the authors concluded that the body had first 279 been outdoors in a warm, sunny environment and was later relocated into the room. However, 280 this conclusion was based on the supposed preference of Lucilia to "oviposit on high temperature 281 surfaces," which the authors interpreted as meaning "outdoors". 
cadaver, but mite species are poorly known and are currently overlooked in forensic entomology.

284 For further information, see Frost et al.'s (2010) abovementioned review and the work of Perotti

285 (Perotti et al., 2009; Frost et al., 2010).

286

287

288

289

290

291

292

293

294

295

296

297

298

299

300

301

302

303

304

Open vs. forest and sunny vs. shaded places

The distinction between open and forest habitat is not always clear: vegetation cover can vary according to season, and the location of a cadaver within an open habitat is not always sunny (e.g., in valleys). In a field study published in 1957, MacLeod and Donnelly found that $C$. vomitoria and L. ampullacea were abundant in regions of dense vegetation (i.e., forest habitats), whereas L. illustris and L. sericata were more common in open conditions (heliophilic species). In general, L. sericata is often found in bright sunlight (Holdaway, 1933), whereas L. caesar is associated with shade (Nuorteva, 1964). However, despite evidence of the thermophilic character of some blow fly species, preferences vary among local populations (Martinez-Sanchez, Rojo \& Marcos-Garcia, 2000; Hwang \& Turner, 2009). For example, Joy, Liette and Harrah (2006) found the same species on sunlit and shaded pig carcasses in West Virginia, USA, and Hwang and Turner (2009) showed the ability of $C$. vicina populations to locally adapt their thermal requirements to suit their environment. In 2012, Lambiase and Camerini reported on the distribution of C. albiceps in northern Italy. During the summer of 2007, two cadavers were discovered next to each other in a mountainous wooded area. The two corpses showed differences in decomposition, and C. albiceps was found only on one corpse, suggesting that the victims were murdered at different times and places. Experiments with baited traps subsequently evidenced the absence of $C$. albiceps at the final location. As this species had recently expanded 
305 into northern Italy, the authors hypothesized that it had not yet reached all suitable habitats,

306 especially those in mountains. Accordingly, they concluded that one corpse was colonized by $C$.

307 albiceps at a lower altitude before being relocated to the mountain. This example of the use of

308 insects to evidence corpse relocation was only possible due to the ongoing expansion of $C$.

309 albiceps in this area. This study highlight the need for local studies and the performance of $a$

310 posteriori experiments over the study of general trends.

311 Regarding coleopterans, Matuszewski, Szafalowicz \& Jarmusz (2013) investigated

312 species that colonized cadavers in open vs. forest habitats. They concluded that the presence of

313 Dermestes frischi, Omosita colon, and Nitidula spp. could be used as evidence of relocation from

314 rural open to rural forest habitat. In contrast, only O. thoracicum was classified as an indicator of

315 relocation in the opposite direction. This conclusion is similar to that of Dekeirsschieter et al.

316 (2011, 2013), who recorded seven Silphidae species in forest habitat (Belgium): all but $O$.

317 thoracica were also sampled in agricultural biotope (open habitat).

318

319 Rural vs. urban

320 The term "synanthropic" is used to characterize species that live near humans and benefit

321 from them and the artificial habitats they create. Cities, and more specifically human activities,

322 are often associated with the production of meat waste that can attract necrophagous insects.

323 Urban areas are characterized by different landscapes: high-rise buildings, urban sprawl,

324 extensive areas of concrete or asphalt surfaces and a variety of infrastructure. These features

325 affect the climate and result in local warming (Wilby, 2003). As ambient temperature is of prime

326 importance for insect activity and development, heat islands such as those observed in large

327 cities can offer thermal refuges for several species. 
Although it is present in both rural and urban habitats, C. vicina tends to be found

329

330

331

332

333

334

335

336

337

predominantly in shady and urban areas (Erzinçlioğlu \& Bunker, 1996; Horenstein et al., 2007;

Greco, Brandmayr \& Bonacci, 2014). In contrast, C. vomitoria is often described as a more rural species that avoids cities (Nuorteva, 1963; Povolny, 1971; Smith, 1986; Hwang \& Turner, 2005, 2009). C. loewi and C. subalpina are also known to avoid urban areas (Nuorteva, 1963; Rognes, 1991; Vanin et al., 2011). In an extensive study examining a 7,000 $\mathrm{km}^{2}$ landscape in Spain, Zabala, Díaze and Saloña-Bordas (2014) found a significant relationship between summer abundance of $C$. vomitoria and both distance to urban areas and degree of urbanization. This pattern was especially clear during the summer, when $C$. vomitoria was significantly more abundant at points far from urban areas. However, for the nine other calliphorid flies they investigated (including C. vicina and L. sericata), no clear synanthropic relationship was found. Several comparative studies on local blow fly populations have been performed in the UK (MacLeod \& Donnelly, 1957a,b; 1960; 1962; Schumann, 1990; Isiche, Hillerton \& Nowell, 1992; Smith \& Wall, 1997; Davies, 1999). Using meat-baited bottle traps, Hwang and Turner (2009) described three groups of necrophagous flies corresponding to three habitat types. The urban habitat was characterized by C. vicina, L. illustris and L. sericata, whereas rural grasslands were inhabited by L. caesar, and the rural woodlands were inhabited by C. vomitoria. Wyss, Cherix \& Mangin (2013) reported that in Switzerland, L. argyrostoma was found in urban areas, whereas C. mortuorum avoided urban areas. Souza and Von Zuben $(2012,2016)$ found significant differences in the extent of synanthropy among some Calliphoridae and Sarcophagidae flies in Brazil. In contrast, in southern Africa, Parry, Mansell and Weldon (2016) observed that the species assemblages present in human-disturbed areas were very similar to those recorded in natural habitats. 
However, most if not all species of forensic interest show inconsistencies or exceptions in

352

353

354

355

356

357

358

359

360

361

362

363

364

365

366

367

368

369

370

371

372

373

their habitat-association patterns. For example, many authors have found that L. sericata is

associated with urban habitats (Nuorteva, 1963; Isiche, Hillerton \& Nowell, 1992; Fisher, Wall

\& Ashworth, 1998; Hwang \& Turner, 2005). A study from Germany found that L. sericata had

the highest Synanthropy Index (SI) of all blow fly species under study (Steinborn, 1981 in Prado

e Castro \& Garcia, 2010). Another German study reported L. sericata and C. vicina as the only

blow fly species caught indoors (Schumann, 1990). Similarly, L. sericata was classified by

Greco, Brandmayr and Bonacci (2014) as the most synanthropic blow fly in Italy. However, $L$.

sericata has also been recorded in natural open habitats in Poland and in open pasture in England

(Smith \& Wall, 1997; Davies, 1999, Matuszewski et al., 2011). In Italy, Vanin et al. (2008) noted

that $L$. sericata does not show a habitat preference in regions with urban sprawl in rural areas and cannot be used to ascertain whether a cadaver has been moved. Regarding L. caesar, Greco,

Brandmayr and Bonacci (2014) observed a preference of this species for wild and rural habitats, a trend supported by some previous studies (Baz et al., 2007; Hwang \& Turner, 2009; Greco, Brandmayr \& Bonacci, 2014) but in conflict with the findings of Fisher, Wall and Ashworth (1998). Thus, while the presence of necrophagous species reflects their ecological preferences, these insects are not sufficiently discretely partitioned between urban and rural areas to be useful in determining corpse relocation in a forensic context.

There are few data on necrophagous coleopterans, likely due to the under-representation of these insects in anthropized environments. Due to their large size and low agility in flight, many Coleoptera species of forensic interest appear to be poorly suited to urban conditions. In 2011, Dekeirsschieter et al. (2011) recorded seven Silphidae species in a Belgian forest environment, six in agricultural biotopes and none in urban locations . According to these results, 
374 silphid beetles may be good indicators of cadaver relocation between rural and urban habitats

375 (Matuszewski et al., 2010; Bala, 2015).

376

377 Other specific locations

378 Water

379 One of the most readily identifiable type of relocation is that from water to open air. In 380 such a case, the presence of any aquatic invertebrate on the cadaver could be evidence of cadaver 381 relocation. In contrast, the finding of the typical necrophagous species on an immersed cadaver 382 can be more challenging to interpret. Merrit and Wallace (2001) described four sequential steps 383 of the change in body position in water over time: 1) the body sinks to the bottom, 2) horizontal 384 movement occurs at the bottom, 3) the body floats to the surface, and 4) surface drift occurs. A 385 cadaver discovered in water during the initial steps is characterized by the absence of the typical 386 necrophagous species (e.g., Calliphoridae species) and the presence of ubiquitous aquatic 387 invertebrates (e.g., Chironomidae larvae, snails). During the first 2 steps of immersion, the cadaver is fully immersed, and the presence of any terrestrial larvae on the cadaver would indicate the eggs were laid before immersion. This possibility is interesting because blow fly larvae can tolerate submersion in water and can remain alive for several hours (Abdel-Shafy et al., 2009; Reigada et al., 2011). However, the finding of the same species on a floating cadaver (steps 3 and 4) would yield less or no information, as many fly species can lay eggs on the emerged parts of a floating cadaver (Tomberlin \& Adler, 1998; Barrios \& Wolff, 2011). The presence of Coleoptera would be more informative for interpreting cadaver relocation. The larvae of most Silphidae species live underneath cadavers and dig pupation

396 chambers into the soil for nymphosis. Thus, the larvae of these species should not be observed on 
397 floating cadavers. Furthermore, large adults are less agile in flight than are flies and thus avoid

398 landing on small surfaces surrounded by water. Barrios and Wolff (2011) did not observe any

399 necrophagous Coleoptera species on pig cadavers placed in two freshwater ecosystems, even

400 during the floating phases. However, Tomberlin \& Adler (1998) observed many small

401 staphylinid beetles on rat carcasses in water and found single adults of the silphid beetle

402 Necrophila americana and the dermestid beetle Dermestes caninus. As dermestid beetles

403 typically colonize and feed on dry materials (Charabidze et al., 2014; Rosenbaum, Devigne \&

404 Charabidze, 2016), their findings highlight the risk associated with drawing conclusions

405 regarding cadaver relocation from general trends.

406 The relocation of a cadaver from a freshwater to marine environment (and the inverse)

407 sometimes occurs, especially where floating cadavers are carried by tides. As most aquatic

408 species are limited to a narrow salinity range, the presence of a given species outside of this

409 range may be evidence of cadaver relocation. Detailed data on species associated with marine

410 and freshwater environments can be found throughout the literature (Sorg et al., 1996; Anderson

411 \& Hobischak, 2004). Cadaver relocation can also occur within the same aquatic environment. In

412 freshwater, the species distribution depends on the physico-chemical attributes of the water

413 (oxygen level, pollutant levels, turbidity), and in running freshwater, there is a succession of

414 habitats and biotopes from source to estuary. For example, Ephemeroptera and Trichoptera

415 larvae are found only in clean and well-oxygenated water, whereas Eristalidae larvae are found

416 in water with a high organic load (Mason, 2002). Abundant literature exists on this topic,

417 especially with respect to bio-indicators (O’Brien et al., 2016).

418

419 Insects of buried/concealed cadavers 

decomposition and access by entomofauna (Simmons et al., 2010). Deep burial and/or protection of the body by a coffin limit but do not prevent post-mortem colonization of the body.

423 Experiments on buried pig carcasses and insect sampling during exhumations have shown the 424 presence of many necrophagous species (Payne, King \& Beinhart, 1968; Smith, 1986;

425 VanLaerhoven \& Anderson, 1999; Bourel et al., 2004; Lefebvre \& Gaudry, 2009; Gaudry, 426 2010). Although no necrophagous species appear to be restricted to buried cadavers, their 427 relative abundance and diversity often differ between buried and exposed cadavers (Braet et al., 428 2015). Thus, the absence of one or more expected species (e.g., calliphorid flies) and the 429 presence of many concealment-related species (e.g., Phoridae) may indicate that a cadaver has 430 been previously buried (Huchet \& Greenberg, 2010; Huchet, 2014).

432 reported that this small fly occurs frequently and in large numbers (Bourel et al., 2004; Martin433 Vega, Gomez-Gomez \& Baz, 2011; Merrit \& al., 2007). The regular occurrence of C. tibialis on 434 buried cadavers reflects this species' behavior: females can burrow through the soil to a depth of $4352 \mathrm{~m}$ to oviposit, and larvae can burrow even deeper (Mozayani \& Noziglia, 2011). Megaselia 436 scalaris is also often found on concealed cadavers. This fly is a warm-climate species, but it has 437 been carried around the world by humans and has been associated with indoor forensic cases in 438 temperate regions (Disney, 2008). However, these two species are present in other environments, 439 including indoors and the open air (Disney, 2012), and their presence cannot be considered 440 definitive evidence of burial. Interestingly, Szpila et al. demonstrated the ability of Phylloteles 441 pictipennis and Eumacronychia persolla (Diptera: Sarcophagidae) to reach deeply buried animal 442 remains and reproduce on this food source (Szpila, Voss \& Pape, 2010). As noted by the authors, 
443 both of these species develop exclusively on buried food resources, making them potential

444 indicators of cadaver relocation.

445 In contrast, common blow flies and muscid flies have limited abilities to colonize buried 446 resources, although Muscina stabulans and M. prolapsa have colonized remains buried up to 40 $447 \mathrm{~cm}$ deep (Gunn \& Bird, 2011). As noted by the authors, the presence of large numbers of larvae 448 of a given species feeding on bodies buried deeper than indicated by their species-specific

449 limitations may be an indication that the body had been exposed above ground for sufficient time 450 for eggs to be laid. Indeed, larvae laid before burying are able to fully develop on cadavers that 451 were subsequently buried (Bachmann \& Simmons, 2010; Gunn \& Bird, 2011). Gunn and Bird 452 (2011) showed the ability of wandering larvae that developed on a buried cadaver to reach the 453 surface and pupate. According to this finding, the presence of pupae on the soil above the grave 454 does not indicate that the cadaver was buried after the pupal stages emerged. Balme et al. (2012) 455 also demonstrated that flies successfully reached the surface following burial at $50 \mathrm{~cm}$ depth as 456 pupae or post-feeding larvae.

457 Mariani et al. (2014) reported the use of an unusual biocenose as evidence of post458 exhumation entomological contamination. Entomological investigation revealed the presence of 459 numerous necrophagous insects as well as omnivorous and storage pests (Dermestidae, 460 Nitidulidae and Tenebrionidae beetles; Tineidae moths; and cockroaches) on exhumed remains. 461 As none of these insects are able to burrow as adults or larvae, their presence is evidence of 462 contamination during storage in the cemetery after exhumation. Other inferences can be drawn 463 from the absence or presence of specific instars, as described in more detail in the section of this 464 review focusing on larval behavior. 
466

467

468

469

470

471

472

473

474

475

476

477

478

479

480

481

482

483

484

485

486

487

488

\section{B. 3 Conclusions related to species-specific habitats}

As described herein in detail, the associations of species to specific habitats can be used to infer cadaver relocation from one habitat to another (Table 1). However, whereas entomological evidence related to species-specific habitats may help support or reject hypotheses regarding cadaver relocation, inferences unsupported by local data are typically not appropriate. Currently, most published information is based on restricted datasets ; future work should focus on obtaining large amounts of data at the local scale. For example, a posteriori analysis of forensic entomology case databases could provide substantial information on the biology of necrophagous species (e.g., species found on indoor vs. outdoor corpses, seasonal prevalence of specific species) (Dekeirsschieter et al., 2013; Disney \& al., 2014; Charabidze et al., 2014, 2016, Syamsa et al., 2017). Back-testing field experiments should always be performed to verify the local applicability of interpretations.

Non-necrophagous species can also provide evidence of cadaver relocation. As reported by Goff (2011): "If a body is outdoors near or under vegetation, it is possible for insects associated with that vegetation to move onto the body, although typically not to feed or lay eggs". However, as these insects are not directly associated with the cadaver, it may be difficult to conclude that they were moved together with it. Furthermore, the probability of having a nonnecrophagous species 1) moving onto a cadaver, 2) being moved with the cadaver, 3) being sampled and identified at the secondary site and 4) being located outside its natural range is likely very low. We have found no report of such a case in the forensic literature.

Table 1. Summary of the presence of necrophagous insects as evidence of cadaver relocation. The first location is represented in the columns, and the second (final) site is represented in the 


\begin{tabular}{|c|c|c|c|c|c|c|c|c|c|}
\hline \multirow{2}{*}{\multicolumn{2}{|c|}{2 - Final location }} & $\begin{array}{c}\text { Indoor } \\
\text { (closed) }\end{array}$ & \multicolumn{2}{|c|}{ Outdoor } & \multirow[b]{2}{*}{ Forest } & \multirow[b]{2}{*}{ Open } & \multirow{2}{*}{$\begin{array}{c}\text { Other } \\
\text { Freshwater }\end{array}$} & \multirow[b]{2}{*}{$\begin{array}{l}\text { Salted } \\
\text { water }\end{array}$} & \multirow[b]{2}{*}{ Buried/Concealed } \\
\hline & & & Rural & Urban & & & & & \\
\hline $\begin{array}{r}\text { Indoor } \\
\text { (closed) }\end{array}$ & & $\mathrm{x}$ & \multicolumn{4}{|c|}{$\begin{array}{l}\text { All usual terrestrial necrophagous } \\
\text { species. Ground-living Coleoptera } \\
\text { larvae would be especially informative }\end{array}$} & \multicolumn{2}{|c|}{$\begin{array}{l}\text { Aquatic species on the } \\
\text { cadaver }\end{array}$} & \\
\hline \multirow[t]{4}{*}{ Outdoor } & Rural & $\begin{array}{c}\text { Mainly } \\
\text { Phoridae, } \\
\text { few } \\
\text { Calliphoridae } \\
\text { (only } \\
\text { Chrysomiinae } \\
\text { pupae, no } \\
\text { wandering } \\
\text { larvae) } \\
\end{array}$ & $\mathrm{x}$ & & & $\mathrm{x}$ & & & $\begin{array}{l}\text { Mainly Phoridae, few } \\
\text { Calliphoridae (no } \\
\text { wandering larvae / only } \\
\text { Chrysomiinae pupae) }\end{array}$ \\
\hline & Urban & & & $\mathrm{x}$ & & & & & \\
\hline & Forest & & & & $x$ & \multicolumn{4}{|c|}{ Lucilia sericata, Dermestes frischi, Omosita colon, Nitidulidae } \\
\hline & Open & & $x$ & & $\begin{array}{c}O . \\
\text { thoracicum }\end{array}$ & $x$ & & & \\
\hline Other & $\begin{array}{l}\text { Freshwater } \\
\text { (immersed) }\end{array}$ & $\begin{array}{c}\text { Many } \\
\text { Phoridae } \\
\text { with only a } \\
\text { few other } \\
\text { terrestrial } \\
\text { species - no } \\
\text { large species }\end{array}$ & \multicolumn{4}{|c|}{$\begin{array}{l}\text { All typical terrestrial necrophagous } \\
\text { species. Ground-living Coleoptera } \\
\text { larvae would be especially informative }\end{array}$} & $\mathrm{x}$ & $\begin{array}{c}\text { Freshwater } \\
\text { species }\end{array}$ & $\begin{array}{l}\text { Many Phoridae with no } \\
\text { other terrestrial species }\end{array}$ \\
\hline & \multicolumn{2}{|c|}{ Saltwater (immersed) } & & & & & $\begin{array}{c}\text { Saltwater } \\
\text { species }\end{array}$ & $\mathrm{x}$ & \\
\hline & \multicolumn{2}{|c|}{ Buried/Concealed } & \multicolumn{4}{|c|}{$\begin{array}{c}\text { Calliphoridae, Sarcophagidae, } \\
\text { Muscidae (possibly other) - all } \\
\text { developmental stages }\end{array}$} & \multicolumn{2}{|c|}{$\begin{array}{l}\text { Aquatic species on the } \\
\text { cadaver }\end{array}$} & $\mathrm{x}$ \\
\hline
\end{tabular}

$X=$ Not possible

Blank: Unknown / Insufficient data

\section{Behavior and development of instars}


499 data are descriptive, consisting of field observations or trends rather than quantitative

500 experiments (Tomberlin et al., 2011). These restrictions make it difficult to draw indisputable

501 conclusions. However, although insect behavior is not always quantifiable, it can be used to

502 construct hypotheses and guide investigations.

503

504 C.1 Adult behavior: colonization and egg laying

505 Egg laying on a cadaver is affected by climatic conditions, species behavior and cadaver

506 accessibility: in theory, these parameters could be used to infer displacement between places

507 with different climactic conditions. Krikken and Huijbregts (2001) reported a neat but

508 questionable example of this concept. Based on the unverified assumption that $L$. sericata

509 females "oviposit on high temperature surfaces," the authors concluded that a cadaver discovered

510 in a room had first been located outdoors in a warm and sunny place. However, although $L$.

511 sericata is heliophilic, it can lay eggs indoors.

512 Though a species-specific minimum temperature is required for egg laying (Hédouin et al., 1996;

513 Faucherre, Cherix \& Wyss, 1999; Ody, Bulling, \& Barnes, 2017), several other weather

514 parameters, such as the levels of sun, wind and rain, can also have effects on egg laying. Fly

515 displacement and egg laying primarily occur during the daytime (Greenberg, 1990; Benecke,

516 1998; Wells et al., 2001). Accordingly, the presence of numerous egg batches on a cadaver

517 located in a dark place suggest the possibility of cadaver relocation. However, Faucherre, Cherix

518 and Wyss (1999) reported a case where C. vicina females had flown to and oviposited on a

519 cadaver in a 10-m-deep cave located in the Swiss Jura mountains, and Gemmellaro et al. (2016)

520 recently demonstrated the ability of some calliphorid flies, especially C. vicina, to reach meat-

521 baited traps placed inside volcanic caves. 
Some species are known to oviposit in specific areas of a cadaver. For example,

523

524

525 526

527 528

529

530

531

532

533

534

535

536

537

538

539

540

541

542

543

544

calliphorid flies preferentially deposit egg batches on the face (nostrils, mouth, eyes), whereas

most silphid beetles lay their eggs underneath the cadaver (Smith, 1986). However, the region of oviposition is strongly affected by the extent of cadaver decomposition or wounds, the presence of other larvae and species, collective behavior (egg aggregation) and environmental characteristics (Charabidze et al., 2015). On the other hand, strong evidence of cadaver relocation is provided by the presence of eggs, especially those of large calliphorids, in inaccessible places, such as underneath a cadaver. Such a case was analyzed in 2013 in France (unpublished data): the presence of numerous L. sericata and C. vicina egg batches in the folds of clothing underneath a cadaver served as evidence of the secondary reversal of the cadaver by drug addicts searching for money.

\section{C.2 Larval development, wandering larvae and pupae}

Fly larvae live on the cadaver and are thus very resistant to cadaver relocation. In contrast, the probability of transferring insects present in the soil or below the cadaver (wandering larvae, pupae and most silphid larvae) along with the cadaver is very low. Accordingly, considerable information can be obtained from the presence and location of wandering larvae and pupae/puparia around a cadaver.

During the post-feeding stage, the larvae of several blow fly species (with the exception of Chrysomyinae species) begin to migrate from the cadaver to pupate in a protected location away from predators (Gomes, Godoy \& Von Zuben, 2006). Greenberg (1990) observed that more than $80 \%$ of post-feeding larvae of $L$. sericata and C. vicina removed of the cadaver to a distance up to $8 \mathrm{~m}$ away. In contrast, only $2 \%$ of $P$. regina, $10 \%$ of $M$. stabulans, and $16 \%$ of $C$. 
545 rufifacies larvae moved away from the cadaver. However, Lewis and Bembow (2011) reported

546 cases of en masse post-feeding dispersal of $P$. regina larvae away from swine carcasses in

547 experiments conducted during the summer. This unexpected observation illustrate the complex

548 behavior of necrophagous larvae and the need for careful analysis before drawing conclusions.

549

550 The presence of necrophagous blow fly pupae and puparia (or dead adult flies) can be

551 evidence of the former presence of a cadaver. This question was extensively discussed during the

552 famous Casey Anthony trial (USA) (Lohr, 2011), in which a first forensic entomologist relied on

553 the presence of numerous M. scalaris larvae, pupae and adults in a car trunk as evidence of the

554 former presence of a cadaver. However, an expert witness for the defense showed that the same

555 insects could have come from a trash bag discovered in the trunk. As the gut contents of insect

556 samples were not tested for DNA, there was no evidence to support the assertion that the insects

557 originated on human remains (Campobasso et al., 2005, see the molecular analysis section of this

558 review). Benecke (2004) described a similar case. The corpse of a man was discovered in the

559 trunk of his car. Only a few larvae and pupae were sampled on the cadaver, but no pupae was

560 found in the gaps of the trunk. The author postulate the cadaver was stored in another place until

561 postfeeding larvae left the corpse. Afterward, the corpse was moved into the car trunk,

562 explaining why only a few maggots were found on the cadaver. Conversely, Krikken and

563 Huijbregts (2001) reported a skeleton found during the winter in a small forest with "numerous

564 empty pupal cocoons of $P$. terraenovae under the bones". Based on the presence of these

565 puparia, the authors concluded that the entire decomposition process had taken place in that same

566 place. However, as this species can pupate in clothes or on decomposing tissues, it is possible

567 that the pupae had been moved together with the cadaver. Lastly, Mariani et al. (2014) observed 
568 that blow fly and muscid larvae buried with a cadaver ultimately left their food source to move to

569 their typical pupariation depths. According to those authors, the presence of large numbers of

570 post-feeding blow fly larvae without a cadaver in the vicinity could indicate that a body may

571 have been buried nearby rather than relocated.

572

573 Cadaver relocation can sometimes be characterized by discrepancies between local

574 temperature and larval development. For example, the presence of third-instar L. sericata

575 individuals on a cadaver located in a cold location (e.g., a cellar with a constant $9-10^{\circ} \mathrm{C}$

576 temperature) would suggest relocation. However, such discrepancies often result from changes in

577 microclimate (e.g., direct sun exposure vs. shade), larval-mass effect or conservation of the

578 samples (e.g., high temperature during transport) rather than from relocation. Cadaver relocation

579 should be considered as a possibility only in the absence of these other influences.

580 In addition, the presence of crushed pupae/imago on or under the cadaver can be

581 indicative of relocation. We observed the presence of flattened pupae or newly hatched flies (flat,

582 dry individuals with a still-visible ptilinum) directly under the cadaver in several forensic cases.

583 In these cases, relocation of the cadaver had likely occurred after numerous flies had started to

584 emerge, and some specimens were compressed under the cadaver during or after moving. If such

585 specimens are observed on site (before the cadaver is moved by the forensic team), relocation

586 after larval pupation might have occurred.

587

588

\section{Phenology and colonization time}

589 The temporal activities of insects vary due to intrinsic properties (e.g., life history,

590 reproductive cycle, development time) and extrinsic seasonal effects (e.g., temperature, 
591 photoperiod and resource availability) (Zabala, Díaz and Saloña-Bordas,2014). Species-specific

592 phenology can therefore be used as an indicator of the season of death and, at least theoretically,

593 of cadaver relocation (Joy, Liette \& Harrah, 2006). For example, the finding of only "late"

594 colonizers on a cadaver with no traces of pioneer species suggests that the cadaver was not

595 accessible to insects during the first stages of decomposition. An example is given by Krikken

596 and Huijbregts (2001): only a small number of insect eggs (attributed to blow flies) were found

597 on a cadaver discovered during a warm summer. Considering the total absence of maggots from

598 the body and the post-mortem interval calculated by the pathologist, the authors concluded that

599 the body must have been sheltered, delaying colonization by blow flies.

600 Madra, Konwerski and Matuszewski (2014) observed clear seasonality trends for 9

601 Staphylininae species and concluded that these species are good candidates as indicators of

602 cadaver relocation. The results for flies are more divergent, and the interactions of phenology

603 and spatial distribution prevent the use of most species as indicators of post-mortem

604 displacement. In the USA, Cammack et al. (2016) reported a significant seasonal effect on the

605 colonization of piglet carrion by blow flies: L. illustris (Meigen) was indicative of spring

606 colonization, Cochliomyia macellaria (F.) and Ch. megacephala (F.) were indicative of summer

607 colonization, and C. vicina and C. vomitoria were indicative of fall colonization. In Spain,

608 Zabala, Díaz and Saloña-Bordas (2014) observed that L. sericata, L. illustris and Ch. albiceps

609 were clear indicators of summer colonization, whereas C. vicina and C. vomitoria were common

610 year round, with maximum abundance in the spring. However, due wide variation with

611 landscape, the authors concluded that these species should not be used as indicators of cadaver

612 relocation. The results from a study in Italy led to a similar conclusion (Greco, Brandmayr \&

613 Bonacci, 2014). Although the authors detected differences in the abundances of Calliphoridae 
614 taxa among sampling months, the effect was strongly dependent on trap location. For example,

615 C. vicina was observed throughout the sampling period (except from June to September) in rural

616 and urban areas but was absent during the cooler months (November to January) in the wild area.

617 Similarly, Vanin et al. (2008) reviewed several Italian forensic cases and concluded that further

618 studies are necessary to confirm whether L. sericata can be used to estimate the season of death.

619

620

Evidence of relocation can also be inferred based on the stage of decomposition at which

621 a necrophagous species colonizes a cadaver. This subject is widely studied and debated within

622 the forensic entomology community. It is well known that some species are early colonizers,

623 whereas others are observed during later stages of decomposition (Smith, 1986). However, the

624 colonization period of a given species varies depending on many parameters, including climate,

625 season, geographic area, local environment, and insect population (Campobasso, Di Vella \&

626 Introna, 2001). These influencing factors must be carefully examined before unusual succession

627 can be considered as evidence of cadaver relocation. Furthermore, open habitats allow easy

628 access to the cadaver for predators or parasites, such as wasps, Silphidae and Cleridae beetles.

629 They can decrease the number and diversity of Diptera larvae, especially if predation occurs

630 during the early developmental stages (e.g., egg removal by wasps). Thus, the absence of some

631 pioneer species does not necessarily indicate cadaver concealment during the first stage of

632 decomposition.

633 Finally, different amounts of time spent in the first location, during transportation and in

634 the secondary decomposition site are associated with different types of evidence. Table 2

635 summarizes the overall scenarios and corresponding timeframes for "simple" cases. However,

636 the problem of time must be considered for each particular case. 
638 Table 2. Effects of time spent in the first (columns) and secondary (lines) decomposition sites on

639 the presence/stage of necrophagous entomofauna. Species and developmental instars on the

640 cadaver can vary with the time spent in each location, affecting the interpretation of

641 entomological samples as evidence of cadaver relocation. Additional details on the

642 entomological phases of the colonization process can be found in Smith (1986).

643

\begin{tabular}{|c|c|c|c|c|c|}
\hline & & \multicolumn{4}{|c|}{ Duration at the 1st deposition site } \\
\hline & & Hours & Days & Weeks & Months/Years \\
\hline \multirow{4}{*}{$\begin{array}{l}\text { Duration } \\
\text { at the } 2 \text { nd } \\
\text { deposition } \\
\text { site }\end{array}$} & Hours & \multirow{4}{*}{$\begin{array}{l}\text { None (duration is insufficient } \\
\text { to sample insects from the 1st } \\
\text { location) }\end{array}$} & $\begin{array}{l}\text { only Calliphoridae } \\
\text { larvae from the 1st } \\
\text { site }\end{array}$ & \multicolumn{2}{|c|}{$\begin{array}{l}\text { various species from the } 1 \text { st site } \\
\text { only }\end{array}$} \\
\hline & Days & & $\begin{array}{l}\text { Calliphoridae larvae } \\
\text { from both sites }\end{array}$ & \multirow{2}{*}{$\begin{array}{l}\text { various species } \\
\text { from the } 1 \text { st } \\
\text { site + late } \\
\text { colonizers from } \\
\text { the } 2 \text { nd site }\end{array}$} & $\begin{array}{l}\text { predominantly } \\
\text { late colonizers } \\
\text { from the 1st } \\
\text { site }\end{array}$ \\
\hline & Weeks & & \multirow{2}{*}{$\begin{array}{l}\text { empty pupae (non- } \\
\text { wandering fly } \\
\text { species) from the 1st } \\
\text { site }\end{array}$} & & $\begin{array}{l}\text { late colonizers } \\
\text { from both sites }\end{array}$ \\
\hline & Months/Years & & & \multicolumn{2}{|c|}{$\begin{array}{l}\text { traces }{ }^{2} \text { of various species from the } \\
\text { 1st site + late colonizers from the } \\
\text { 2nd site }\end{array}$} \\
\hline
\end{tabular}

644

645

646

E. Contribution of molecular analyses

647

\section{E. 1 Cuticular hydrocarbons}

648

The ability to identify forensic species at different developmental stages and their

649 associations with local populations can be crucial in determining whether a body was moved

650 from a crime scene. Simple molecular analyses concern cuticular hydrocarbon profiles. Insects

651 form a thin, epicuticular layer of wax consisting of free lipids, which is a class of compounds

652 that includes hydrocarbons, alcohols, fatty acids, waxes, acylglycerides, phospholipids and

653 glycolipids (Gibbs \& Elizabeth, 1998). The cuticular hydrocarbon phenotype is biologically very 
654 stable and almost entirely determined by genotype (Wells \& Stevens, 2009; Pechal et al., 2014).

655 Byrne et al. (1995) demonstrated that the cuticular hydrocarbons of three geographically distinct 656 populations of $P$. regina are differentiable. However, some local populations can interbreed with 657 adjacent populations, and the minimal interval over which adjacent populations can be 658 considered distinct remains unknown. Accordingly, this method could be used to identify the 659 presence of a non-local population on a cadaver (which suggests cadaver relocation) but will not 660 be informative in cases of short-distance relocation (Byrne et al., 1995). More research on this 661 promising topic should be conducted in the future (Tomberlin \& al., 2011).

662

\section{E. 2 Genetics of insect populations}

664 DNA-based identification is valuable for identifying adult insects of forensic interest as 665 well as immature stages, cuticle fragments and puparia (Sperling, Anderson \& Hickey, 1994; Zehner et al., 2004; Guo et al., 2010; Li et al., 2010; Wells \& Sperling, 2001; Mazzanti et al., 2010; Xinghua et al. 2010; Guo et al., 2011; Zaidi et al., 2011; Jordaens et al., 2013;

Meiklejohn, Wallman \& Downton, 2013; Park et al., 2013, Sonet et al., 2013). If post-mortem 669 changes are suspected, relocation can be evidenced by determining the relationships between 670 insects sampled at the initial and secondary sites (Picard, Villet \& Wells, 2012). Several studies

671 have highlighted significant genetic differences between populations of the same species within 672 (BoehmeHall et al., 2001; Desmyter \& Gosselin, 2009; Sonet et al., 2013) and among continents 673 (Hall et al., 2001; Lyra et al., 2005). To identify genetic variation among populations, methods 674 such as simple conformation polymorphism strand analysis (SSCP) and AFLP (amplified 675 fragment length polymorphism) are available. However, kinship analyses require a solid genetic 676 database that encompasses variability among geographical sites, the development of which 
677 requires thorough field sampling, precise morphological identification and the complete genetic 678 characterization of each collected individual.

679 Databases such as GenBank and the Barcode of Life Data Systems (BOLD) have been 680 used to detect genetic variation within local populations of the same species (Wells \& Stevens, 681 2009). Using SSCP analysis, inter-population differences have been detected between African 682 and North American populations of the common housefly, Musca domestica (Marquez \& 683 Krafsur, 2003). Harvey et al. (2003) found differences in the COI gene between South African 684 and Australian populations of two species of forensic interest, Chrysomya rufifacies and $L$. 685 cuprina. Furthermore, Desmyter and Gosselin (2009) and Boehme, Amendt and Zehner (2012) 686 found sequence differences between Phormia regina specimens from North America and 687 Europe. Jordaens et al. (2013) confirmed this divergence in the COI gene between P. regina 688 populations with newly sequenced material. However, sequence divergence within each 689 continent was only ca. $0.4 \%$, making genetic differentiation of local strains difficult to detect. At 690 the local scale, blow flies show genetic isolation by time but not distance. Scientific projects 691 dedicated to building datasets that reflect the diversity of necrophagous entomofauna at the 692 European scale are currently expanding and are expected to address this topic in the near future 693 (Sonet et al., 2013; Geiger et al., 2016).

694 Using AFLP surveys, Picard and Wells observed that groups of adult L. sericata and $P$. 695 regina individuals trapped together on a bait were predominantly composed of related 696 individuals, with a level of genetic diversity lower than that observed at a larger scale (Picard \& 697 Wells, 2009, 2010). This pattern is also observed in gravid females and is likely exhibited by 698 larvae, suggesting that the population genetic structure of adults could be extended to the larval 699 population growing on a cadaver. Such a finding would support the potential use of genetic tests 
700 to infer post-mortem relocation of a cadaver: for example, a larva found in one location might

701 belong to a larval population growing on a cadaver in a second location. Faulds, Wells and

702 Picard (2014) confirmed the validity of the AFLP method, finding that kinship testing based on

703 AFLP data yielded adequate kinship estimates with limited error. As noted by those authors, this

704 type of analysis can be performed on any life stage of the insect and on any species. Regarding

705 species of interest in forensic entomology, AFLP data are currently available for P. regina, L.

706 sericata and C. megacephala (Picard \& Wells, 2009, 2010; Bao \& Wells, 2014). AFLP analysis

707 of full sibship is a promising method for the detection of post-mortem relocation.

708 Many interesting ideas and examples can be found in the literature on wildlife genetic

709 geographic origin assignment. DNA testing, which relies on the assignment of an unknown

710 sample to its genetic population of origin, has become a widespread tool in wildlife forensic

711 science. The excellent review by Ogden and Linacre (2015) provides not only examples and

712 detailed methods of DNA testing but also valuable consideration on its use in court. As noted in

713 the review, the availability and quality of reference data are of paramount importance and are

714 currently the main disincentive of the application of DNA-based methods in the field of forensic

715 entomology.

716

717 E. 3 Identification of human DNA

718 Another contribution of molecular analysis is the identification of human DNA in the

719 digestive tract of the larvae. This method can be used to determine the genetic profile of the 720 victim (Campobasso, Di Vella \& Introna, 2001; Wells \& Sperling, 2001; Benecke \& Wells,

721 2002) and can be used as evidence in the absence of a cadaver and after the cadaver's relocation

722 (Gaudry et al., 2007). The presence of necrophagous larvae or pupae in an otherwise barren 
723 location can suggest the former presence of a cadaver. If genetic analysis of the gut contents of

724 such larvae reveals the victim's DNA, entomological evidence can be used to infer relocation

725 (Wells et al., 2001; Lohr, 2011). In 2001, Wells et al. demonstrated that mitochondrial DNA

726 sequences can be obtained from the dissected gut of a maggot that had fed on human tissue. In

727 2013, Chaves-Briones et al. reported the first forensic case of victim identification from human

728 DNA isolated from the gastrointestinal tract of necrophagous larvae. Njau et al. (2016)

729 demonstrated that DNA analysis could be used to determine whether the larvae sampled on a

730 cadaver were introduced from an alternative food source (e.g., a dead animal or a trash can near

731 the cadaver). However, due to the rapid degradation of DNA by gut digestive enzymes, such

732 analyses are limited to two days post-feeding (Picard \& Wells, 2009; Charabidze, Hedouin \&

733 Gosset, 2013). Such restriction may change in a near future: a recent paper by Pilli et al. (2016)

734 successfully used Next Generation Sequencing to obtain a human profile from the

735 gastrointestinal tract of head lice. Additional more striking evidence of the potential of this

736 method was provided by Marchetti et al. (2013) and Madra, Konwerski and Matuszewski (2014).

737 They used short tandem repeat (STR) analysis to extract and type human DNA from empty

738 puparia collected in two forensic cases. As puparia cases are highly durable, they offer a unique

739 opportunity to indicate cadaver relocation a long time after the event.

740

741 F. Conclusions

742 1/ The issue of cadaver relocation has arisen in many forensic cases and has received particular

743 attention in forensic entomology.

744 2/ Although some species are preferentially found in specific biotopes, most are not sufficiently

745 geographically restricted to serve as indicators of cadaver relocation. 
746 3/ Time is a key factor influencing the presence of necrophagous insects. A cadaver that remains

747 only briefly in the first location is unlikely to be colonized by local insects, whereas a cadaver

748 that remains for a very long period will have been abandoned by insects before cadaver

749 relocation occurs.

750 4/ Circumstances that allow the clear inference of corpse relocation based on cadaver

751 entomofauna are the following:

752 - relocation from open air to an aquatic environment (and vice versa),

753 - relocation from open air to a grave or burial site (and vice versa),

754 - removal from an indoor location at which some larvae or pupae remain, and

755 - genetic associations between larval populations or identification of human DNA.

$7565 /$ Only field studies performed at the local scale and focused on a clear question (e.g.,

757 differences between indoor and outdoor entomofauna) should be used as references.

758 6/ We recommend that forensic entomologists perform local trapping and experiments $a$

759 posteriori to comply with the circumstances of a given forensic case. Corpse relocation

760 inferences should not be based on general trends or previous results at a broader scale.

761 7/ Analyses should be performed only by trained forensic entomologists and require early

762 discussion with investigators, extensive on-site sampling, and the conservation and analysis of

763 relevant samples, and a considerable amount of chance.

764 8/ Future work should focus on sharing and analyzing forensic entomology case databases. Such

765 studies are less time-consuming than field experiments and can reflect a variety of

766 circumstances; thus, they have the potential to provide abundant information on the biology of

767 necrophagous species of forensic interest. 
769

770

771

772

773

774

775

776

777

778

779

780

781

782

783

784

785

786

787

788

789

790

\section{G. References}

Abd El-Bar MM, Sawaby RF. 2011. A preliminary investigation of insect colonization and succession on remains of rabbits treated with an organophosphate insecticide in ElQalyubiya Governorate of Egypt. Forensic Science International 208:e26-e30. DOI: 10.1016/j.forsciint.2010.10.007.

Abdel-Shafy S, El-Khateeb RM, Soliman MM, Abdel-Aziz MM. 2009. The efficacy of some wild medicinal plant extracts on the survival and development of third instar larvae of Chrysomyia albiceps (Wied) (Diptera: Calliphoridae). Tropical Animal Health and Production 41:1741-1753. DOI: 10.1007/s11250-009-9373-0.

Abouzied EM. 2014. Insect colonization and succession on rabbit carcasses in southwestern mountains of the kingdom of Saudi Arabia. Journal of Medical Entomology 51:11681174. DOI: $10.1603 / \mathrm{me} 13181$.

Ali Hanafi-Bojd A, Yaghoobi-Ershadi MR, Haghdoost AA, Akhavan AA, Rassi Y, Karimi A, Charrahy Z. 2015. Modeling the distribution of cutaneous leishmaniasis vectors (Psychodidae: Phlebotominae) in Iran: a potential transmission in disease prone areas. Journal of Medical Entomologyomol 52:557-565. DOI: 10.1093/jme/tjv058.

Anderson GS, Hobischak NR. 2004. Decomposition of carrion in the marine environment in British Columbia, Canada. International Journal of Legal Medicine 118:206-209. DOI: $10.1007 / \mathrm{s} 00414-004-0447-2$.

Anderson GS, Van Laerhoven SL. 1996. Initial studies on insect succession on carrion in southwestern British Columbia. Journal of Forensic Sciences 41:617-625. DOI: 10.1520/JFS13964J. 
791 Anderson GS. 2011. Comparison of decomposition rates and faunal colonization of carrion in 792 indoor and outdoor environments. Journal of Forensic Sciences 56:136-142. DOI:

793 10.1111/j.1556-4029.2010.01539.x.

794

795

796

797

798

799

800

801

802

803

804

805

806

807

808

809

810

811
Anthony Case Discovery Trunk Report. Scribd. Available at https://fr.scribd.com/document/50549784/Anthony-Case-Discovery-Trunk-Report (accessed 23 May 2017).

Archer M. 2014. Comparative analysis of insect succession data from Victoria (Australia) using summary statistics versus preceding mean ambient temperature models. Journal of Forensic Sciences 59:404-412. DOI: 10.1111/1556-4029.12345.

Archer MS, Wallman JF. 2016. Context effects in forensic entomology and use of sequential unmasking in casework. Journal of Forensic Sciences 61:1270-1277. DOI: $10.1111 / 1556-4029.13139$.

Bachmann J, Simmons T. 2010. The influence of preburial insect access on the decomposition rate. Journal of Forensic Sciences 55:893-900. DOI: 10.1111/j.1556-4029.2010.01403.x.

Bala M. 2015. Beetles and forensic entomology: a comprehensive review. Journal of Entomological Research 39:293-302. DOI: 10.5958/0974-4576.2015.00036.5.

Balme GR, Denning SS, Cammack JA, Watson DW. 2012. Blow flies (Diptera: Calliphoridae) survive burial: evidence of ascending vertical dispersal. Forensic Science International 216:e1-e4. DOI: 10.1016/j.forsciint.2011.07.017.

Bao F, Wells JD. 2014. Population genetic structure of an invasive forensically important insect. Electrophoresis 35:3193-3200. DOI: 10.1002/elps.201400108. 
812 Barrios M, Wolff M. 2011. Initial study of arthropods succession and pig carrion decomposition 813 in two freshwater ecosystems in the Colombian Andes. Forensic Science International 814 212:164-172. DOI: 10.1016/j.forsciint.2011.06.008.

815 Baz A, Cifrián B, Díaz-äranda LM, Martín-Vega D. 2007. The distribution of adult blow-flies 816 (Diptera: Calliphoridae) along an altitudinal gradient in Central Spain. Annales de la Société Entomologique de France 43:289-296. DOI: 10.1080/00379271.2007.10697524.

818

819

820

821

822

823

824

825

826

827

828

829

830

831

832

Benecke M, Wells J. 2002. DNA techniques for forensic entomology. In: Byrd JH, and Castner JL, eds. Forensic entomology: the utility of arthropods in legal investigations, 2nd Ed. Boca Raton, FL: CRC Press, 341-352.

Benecke M. 1998. Six forensic entomology cases: description and commentary. Journal of Forensic Sciences 43:797-805. DOI: 10.1520/JFS14309J.

Benecke M. 2001. A brief history of forensic entomology. Forensic Science International 120:214. DOI: $10.1016 / \mathrm{S} 0379-0738(01) 00409-1$.

Benecke M. 2004. Arthropods and corpses. Forensic Pathology Reviews 2:207-240.

Boehme P, Amendt J, Zehner R. 2012. The use of COI barcodes for molecular identification of forensically important fly species in Germany. Parasitology Research 110:2325-2332. DOI: $10.1007 / \mathrm{s} 00436-011-2767-8$.

Boehme P, Spahn P, Amendt J, Zehner R. 2013. Differential gene expression during metamorphosis: a promising approach for age estimation of forensically important Calliphora vicina pupae (Diptera: Calliphoridae). International Journal of Legal Medicine 127:243-249. DOI: 10.1007/s00414-012-0699-1. 
833 Bomphrey RJ, Walker SM, Taylor GK. 2009. The typical flight performance of blowflies:

834 measuring the normal performance envelope of Calliphora vicina using a novel Corner835 cube arena. PLoS One 4:e7852. DOI: 10.1371/journal.pone.0007852.

836 Bourel B, Martin-Bouyer L, Hedouin V, Cailliez JC, Derout D, Gosset D. 1999. Necrophilous 837 insect succession on rabbit carrion in sand dune habitats in Northern France. Journal of

839 Bourel B, Tournel G, Hédouin V, Gosset D. 2004. Entomofauna of buried bodies in Northern France. International Journal of Legal Medicine 118:215-220. DOI: 10.1007/s00414004-0449-0. Medical Entomology 36:420-425. DOI: 10.1093/jmedent/36.4.420. Review of Entomology 38:1-23. DOI: 10.1146/annurev.en.38.010193.000245.

847 Brundage A, Bros S, Honda JY. 2011. Seasonal and habitat abundance and distribution of some 848 forensically important blow flies (Diptera: Calliphoridae) in Central California. Forensic Science International 212:115-120. DOI: 10.1016/j.forsciint.2011.05.023.

Byrd JH, Castner JL. 2009. Forensic entomology: the utility of arthropods in legal investigations. 2nd Ed. Boca Raton: CRC Press. biochemical differences among geographic populations of the black blow fly, Phormia regina (Meigen). Journal of Forensic Sciences 40:372-377. DOI: 10.1520/JFS13789J. 
855 Cainé LM, Real FC, Saloña-Bordas MI, Pancorbo MM, Lima G, Magalhães T, Pinheiro F. 2009.

856 DNA typing of Diptera collected from human corpses in Portugal. Forensic Science

857 International 184:e21-e23. DOI: 10.1016/j.forsciint.2008.10.016.

858 Calvignac-Spencer S, Merkel K, Kutzner N, Kühl H, Boesch C, Kappeler PM, Metzger S,

859 Schubert G, Leendertz FH. 2013. Carrion fly-derived DNA as a tool for comprehensive

860 and cost-effective assessment of mammalian biodiversity. Molecular Ecology 22:915-

861924 . DOI: $10.1111 / \mathrm{mec} .12183$.

862 Cammack JA, Cohen AC, Kreitlow KL, Roe RM, Watson DW. 2016. Decomposition of 863 concealed and exposed porcine remains in the North Carolina Piedmont. Journal of 864 Medical Entomology 53:67-75. DOI: 10.1093/jme/tjv183.

865 Campobasso CP, Di Vella G, Introna F. 2001. Factors affecting decomposition and Diptera 866 colonization. Forensic Science International 120:18-27. DOI: 10.1016/S0379$867 \quad$ 0738(01)00411-X.

868 Campobasso CP, Linville JG, Wells JD, Introna F. 2005. Forensic genetic analysis of insect gut 869 contents. The American Journal of Forensic Medicine and Pathology 26:161-165.

870 Castro CP, García MD. 2010. First record of chrysomya megacephala (Fabricius, 1794) (Diptera, 871 Calliphoridae) from Portugal. Graellsia 65:75-77. DOI:

$872 \quad$ 10.3989/graellsia.2009.v65.i1.139.

873 Castro CP, Szpila K, Rego C, Boieiro M, Serrano ARM. 2016. First finding of larviposition in 874 Calliphora loewi from an island relict forest. Entomological Science 19:77-81. DOI:

$875 \quad 10.1111 /$ ens.12163.

876 Catts EP, Goff ML. 1992. Forensic entomology in criminal investigations. Annual Review of 877 Entomology 37:253-272. DOI: 10.1146/annurev.en.37.010192.001345. 
878 Centeno N, Maldonado M, Oliva A. 2002. Seasonal patterns of arthropods occurring on sheltered 879 and unsheltered pig carcasses in Buenos Aires Province (Argentina). Forensic Science 880 International 126:63-70. DOI: 10.1016/S0379-0738(02)00037-3.

881 Charabidze D, Colard T, Vincent B, Pasquerault T, Hedouin V. 2014. Involvement of larder 882 beetles (Coleoptera: Dermestidae) on human cadavers: a review of 81 forensic cases. International Journal of Legal Medicine 128:1021-1030. DOI: 10.1007/s00414-013-

884 0945-1.

885

886

887

888

889

890

891

892

893

894

895

896

897

898

899

900

Charabidze D, Depeme A, Devigne C, Hedouin V. 2015. Do necrophagous blowflies (Diptera: Calliphoridae) lay their eggs in wounds? Experimental data and implications for forensic entomology. Forensic Science International 253:71-75. DOI: 10.1016/j.forsciint.2015.05.025.

Charabidze D, Hedouin V, Gosset D. 2013. Discontinuous foraging behavior of necrophagous Lucilia sericata (Meigen 1826) (Diptera Calliphoridae) larvae. Journal of Insect Physiology 59:325-331. DOI: 10.1016/j.jinsphys.2012.12.006.

Charabidze D, Hedouin V, Gosset D. 2015. An experimental investigation into the colonization of concealed cadavers by necrophagous blowflies. Journal of Insect Science 15:149-149. DOI: $10.1093 /$ jisesa/iev129.

Charabidze D, Vincent B, Pasquerault T, Hedouin V. 2016. The biology and ecology of Necrodes littoralis, a species of forensic interest in Europe. International Journal of Legal Medicine 130:273-280. DOI: 10.1007/s00414-015-1253-8.

Chauvet B, Dourel L, Vincent B, Pasquerault T, Gaudry E. 2008. Répartition des Nicrophorus F., 1775 récoltés sur des cadavres humains (Coleoptera: Silphidae). L'Entomologiste 64:15-20. 
901 Chavez-Briones ML, Hernandez-Cortes R, Diaz-Torres P, Niderhauser-Garcia A, Ancer902 Rodriguez J, Jaramillo-Rangel G, Ortega-Martinez M. 2013. Identification of human

903

904 remains by DNA analysis of the gastrointestinal contents of fly larvae. Journal of 905 Forensic Sciences 58:248-250. DOI: 10.1111/j.1556-4029.2012.02279.x.

Davies L. 1990. Species composition and larval habitats of blowfly (Calliphoridae) populations 906

907 in upland areas in England and Wales. Medical and Veterinary Entomology 4:61-68.

908

Davies L. 1999. Seasonal and spatial changes in blowfly production from small and large 909 carcasses at Durham in lowland northeast England. Medical and Veterinary Entomology

910 13:245-251. DOI: 10.1046/j.1365-2915.1999.00135.x.

911 de Souza CR, Von Zuben CJ. 2016. Synanthropy of Sarcophagidae (Diptera) in southeastern 912 Brazil. Neotropical Entomology 45:637-641. DOI: 10.1007/s13744-016-0411-0.

913 de Souza CR, Zuben CJ. 2012. Diversity and synanthropy of Calliphoridae (Diptera) in the 914 region of Rio Claro, SP, Brazil. Neotropical Entomology 41:243-248. DOI:

915 10.1007/s13744-012-0037-9.

916 Dekeirsschieter J, Frederickx C, Verheggen FJ, Boxho P, Haubruge E. 2013. Forensic entomology investigations from Doctor Marcel Leclercq (1924-2008): a review of cases from 1969 to 2005. Journal of Medical Entomology 50:935-954. DOI:

919 10.1603/ME12097.

Dekeirsschieter J, Verheggen FJ, Haubruge E, Brostaux Y. 2011. Carrion beetles visiting pig 921 carcasses during early spring in urban, forest and agricultural biotopes of Western Europe. Journal of Insect Science 11:73. DOI: 10.1673/031.011.7301. 
923 Desmyter S, Gosselin M. 2009. COI sequence variability between Chrysomyinae of forensic 924 interest. Forensic Science International: Genetics 3:89-95. DOI:

925 10.1016/j.fsigen.2008.11.002.

926

927

928

929

930

931

932

933

934

935

936

937

938

939

940

941

942 Fisher P, Wall R, Ashworth JR. 1998. Attraction of the sheep blowfly, Lucilia sericata (Diptera:

943

944

Disney RH. 2008. Natural history of the scuttle fly, Megaselia scalaris. Annual Review of Entomology 53:39-60. DOI: 10.1146/annurev.ento.53.103106.093415.

Disney RH. 2012. Scuttle flies: the phoridae. Scarborough, UK: Chapman \& Hall.

Disney RH, Garcia-Rojo A, Lindström A, Manlove JD. 2014. Further occurrences of Dohrniphora cornuta (Bigot) (Diptera, Phoridae) in forensic cases indicate likely importance of this species in future cases. Forensic Science Internationa 241:e20-2.

Ebejer MJ. 2007. The occurrence of Chrysomya megacephala (Fabricius)(Diptera, Brachycera) in Malta and records of other Calliphoridae from the Maltese Islands. Entomologists Monthly Magazine 143:165-170.

Erzinçlioğlu Z, Bunker S. 1996. Blowflies. Slough: The Richmond Publishing Co. Ltd.

Faucherre J, Cherix D, Wyss C. 1999. Behavior of Calliphora vicina (Diptera, Calliphoridae) under extreme conditions. Journal of Insect Behavior 12:687-690. DOI: 10.1023/a:1020931804597.

Faulds KJ, Wells JD, Picard CJ. 2014. Verification of AFLP kinship methods of entomological evidence by sequencing. Forensic Science International 245:58-62. DOI: 10.1016/j.forsciint.2014.09.024. Calliphoridae) to carrion bait in the field. Bulletin of Entomological Research 88:611. DOI: $10.1017 / \mathrm{s} 0007485300054274$. 
945 Frost C, Braig H, Amendt J, Perotti M. 2010. Indoor arthropods of forensic importance: insects

946

947

948

949

950

951

952

953

954

955

956

957

958

959

960

961

962

963

964

965

966 associated with indoor decomposition and mites as indoor markers. In: Amendt J, Goff ML, Campobasso CP, and Grassberger M, eds. Current concepts in forensic entomology. Netherlands: Springer, 93-108.

Gaudry E, Dourel L, Chauvet B, Vincent B, Pasquerault T. 2007. L'entomologie légale lorsque insecte rime avec indice. Revue Francophone des Laboratoires 2007:23-32. DOI: 10.1016/S1773-035X(06)80636-2.

Gaudry E. 2010. The insects colonisation of buried remains. In: Amendt J, Goff ML, Campobasso CP, and Grassberger M, eds. Current concepts in forensic entomology. Dordrecht: Springer Netherlands, 273-311.

Global Biodiversity Information Facility (GBIF) Database, Cynomya mortuorum Distribution Map accessed via GBIF.org on 9 september 2016. Available at http://www.gbif.org/species/1502142.

Geiger MF, Astrin JJ, Borsch T, Burkhardt U, Grobe P, Hand R, Hausmann A, Hohberg K, Krogmann L, Lutz M, Monje C, Misof B, Morinière J, Müller K, Pietsch S, Quandt D, Rulik B, Scholler M, Traunspurger W, Haszprunar G, Wägele W. 2016. How to tackle the molecular species inventory for an industrialized nation-lessons from the first phase of the German Barcode of Life initiative GBOL (2012-2015). Genome 59(9):661-70.

Gemmellaro M. 2016. First survey insects of forensic importance in Sicily and it's volcanic caves. In: European association for forensic eentomology conference. Budapest, Hungria. German Barcode of Life. Deutschlands Fauna und Flora in einer einzigartigen genetischen bibliothek. 
967 Gibbs AG, Elizabeth LC. 1998. The biology of lipids: integrative and comparative perspectives. $968 \quad$ American Zoologist 38:265-267. DOI: 10.1093/icb/38.2.265.

969 Goff ML. 1991. Comparison of insect species associated with decomposing remains recovered 970 inside dwellings and outdoors on the island of Oahu, Hawaii. Journal of Forensic 971 Sciences 36:748-753. DOI: 10.1520/JFS13085J.

972 Goff ML. 2011. Forensic entomology. In: Mozayani A, and Noziglia C, eds. The forensic 973 laboratory handbook procedures and practice. Totowa, NJ: Humana Press, 447-478.

974 Gomes L, Godoy WA, Von Zuben CJ. 2006. A review of postfeeding larval dispersal in

975

976

977

978

979

980

981

982

983

984

985

986

987

988

989 blowflies: implications for forensic entomology. Naturwissenschaften 93:207-215. DOI: 10.1007/s00114-006-0082-5.

Grassberger M, Friedrich E, Reiter C. 2003. The blowfly Chrysomya albiceps (Wiedemann) (Diptera: Calliphoridae) as a new forensic indicator in Central Europe. International Journal of Legal Medicine 117:75-81. DOI: 10.1007/s00414-002-0323-X.

Greco S, Brandmayr P, Bonacci T. 2014. Synanthropy and temporal variability of Calliphoridae living in Cosenza (Calabria, southern Italy). Journal of Insect Science 14. DOI: 10.1093/jisesa/ieu078.

Greenberg B. 1990a. Behavior of postfeeding larvae of some Calliphoridae and a muscid (Diptera). Annals of the Entomological Society of America 83:1210-1214. DOI: 10.1093/aesa/83.6.1210.

Greenberg B. 1990b. Nocturnal oviposition behavior of blow flies (Diptera: Calliphoridae). Journal of Medical Entomology 27:807-810. DOI: 10.1093/jmedent/27.5.807.

Gunn A, Bird J. 2011. The ability of the blowflies Calliphora vomitoria (Linnaeus), Calliphora vicina (Rob-Desvoidy) and Lucilia sericata (Meigen) (Diptera: Calliphoridae) and the 
990

991

992

993

994

995

996

997

998

999

1000

1001

1002

1003

1004

1005

1006

1007

1008

1009

1010

1011

muscid flies Muscina stabulans (Fallen) and Muscina prolapsa (Harris) (Diptera:

Muscidae) to colonise buried remains. Forensic Science International 207:198-204. DOI: 10.1016/j.forsciint.2010.10.008.

Guo Y, Cai J, Chang Y, Li X, Liu Q, Wang X, Wang X, Zhong M, Wen J, Wang J. 2011. Identification of forensically important sarcophagid flies (Diptera: Sarcophagidae) in China, based on COI and 16S rDNA gene sequences. Journal of Forensic Sciences 56:1534-1540. DOI: 10.1111/j.1556-4029.2011.01882.x.

Guo YD, Cai JF, Li X, Xiong F, Su RN, Chen FL, Liu QL, Wang XH, Chang YF, Zhong M, Wang X, Wen JF. 2010. Identification of the forensically important sarcophagid flies Boerttcherisca peregrina, Parasarcophaga albiceps and Parasarcophaga dux (Diptera: Sarcophagidae) based on COII gene in China. Tropical Biomedicine 27:451-460.

Haglund W, Sorg M. 1997. Forensic taphonomy: the postmortem fate of human remains. Boca Raton, FL: CRC Press.

Hall MJ, Edge W, Testa JM, Adams ZJ, Ready PD. 2001. Old world screwworm fly, Chrysomya bezziana, occurs as two geographical races. Medical and Veterinary Entomology 15:393402. DOI: 10.1046/j.0269-283x.2001.00327.x.

Harvey ML, Mansell MW, Villet MH, Dadour IR. 2003. Molecular identification of some forensically important blowflies of southern Africa and Australia. Medical and Veterinary Entomology 17:363-369. DOI: 10.1111/j.1365-2915.2003.00452.x.

Hédouin V, Martin-Bouyer L, Bourel B, Revuelta E, Gosset D. 1996. Influence de la température sur la ponte des diptères: application à l'entomologie médico-légale. Journal de Médecine Légale Droit Médical 39:153-157. 
1012 Holdaway FG. 1933. Differential Behaviour of Lucilia sericata Meig. and Lucilia caesar L. in 1013 natural environments. Journal of Animal Ecology 2:263-265. DOI: 10.2307/962.

1014 Horenstein MB, Linhares AX, Rosso B, García MD. 2007. Species composition and seasonal 1015 succession of saprophagous calliphorids in a rural area of Córdoba: Argentina. Biological 1016 Research 40:163-171. DOI: 10.4067/S0716-97602007000200007.

1017 Huchet JB, Greenberg B. 2010. Flies, Mochicas and burial practices: a case study from Huaca de 1018 la Luna, Peru. Journal of Archaeological Science 37:2846-2856. DOI:

1019 10.1016/j.jas.2010.06.025.

1020 1021

1022 1023

1024

1025

1026

1027

1028

1029

1030

1031

1032

1033

1034

Huchet J-B. 2014. Insect remains and their traces: relevant fossil witnesses in the reconstruction of past funerary practices. Anthropologie 52:329-346.

Hwang C, Turner BD. 2005. Spatial and temporal variability of necrophagous Diptera from urban to rural areas. Medical and Veterinary Entomology 19:379-391. DOI: 10.1111/j.1365-2915.2005.00583.x.

Hwang CC, Turner BD. 2009. Small-scaled geographical variation in life-history traits of the blowfly Calliphora vicina between rural and urban populations. Entomologia Experimentalis et Applicata 132:218-224. DOI: 10.1111/j.1570-7458.2009.00891.x.

Isiche J, Hillerton JE, Nowell F. 1992. Colonization of the mouse cadaver by flies in southern England. Medical and Veterinary Entomology 6:168-170. DOI: 10.1111/j.13652915.1992.tb00597.x.

Johnson DH. 1980. The comparison of usage and availability measurements for evaluating resource preference. Ecology 61:65-71. DOI: 10.2307/1937156.

Jordaens K, Sonet G, Richet R, Dupont E, Braet Y, Desmyter S. 2013. Identification of forensically important Sarcophaga species (Diptera: Sarcophagidae) using the 
1035

1036

1037

1038

1039

1040

1041

1042

1043

1044

1045

1046

1047

1048

1049

1050

1051

1052

1053

1054

1055

1056

1057

mitochondrial COI gene. International Journal of Legal Medicine 127:491-504. DOI: 10.1007/s00414-012-0767-6.

Joseph I, Mathew DG, Sathyan P, Vargheese G. 2011. The use of insects in forensic investigations: an overview on the scope of forensic entomology. Journal of Forensic Dental Sciences 3:89-91. DOI: 10.4103/0975-1475.92154.

Joy JE, Liette NL, Harrah HL. 2006. Carrion fly (Diptera: Calliphoridae) larval colonization of sunlit and shaded pig carcasses in West Virginia, USA. Forensic Science International 164:183-192. DOI: 10.1016/j.forsciint.2006.01.008.

Krikken J, Huijbregts J. 2001. Insects as forensic informants: the Dutch experience and procedure. Proceedings of the Section Experimental and Applied EntomologyNetherlands Entomological Society 12:159-164.

Kumar S, Yee WL, Neven LG. 2016. Mapping global potential risk of establishment of Rhagoletis pomonella (Diptera: Tephritidae) using MaxEnt and CLIMEX niche models. Journal of Medical Entomologyomol 109:2043-2053.

Kurahashi H, Kuranishi RB. 2000. Calliphorid and sarcophagid flies (Insecta: Diptera) collected from the Kamchatka Peninsula and North Kuril Islands in 1996-1997. Natural History Research Special Issue 7:179-180.

Lambiase S, Camerini G. 2012. Spread and habitat selection of Chrysomya albiceps (Wiedemann) (Diptera Calliphoridae) in Northern Italy: forensic implications. Journal of Forensic Sciences 57:799-801. DOI: 10.1111/j.1556-4029.2011.02027.x.

Lefebvre F, Gaudry E. 2009. Forensic entomology: a new hypothesis for the chronological succession pattern of necrophagous insect on human corpses. Annales de la Société entomologique de France (N.S.) 45:377-392. DOI: 10.1080/00379271.2009.10697622. 
1058 Lewis AJ, Benbow ME. 2011. When entomological evidence crawls away: Phormia regina en 1059 masse larval dispersal. Journal of Medical Entomology 48:1112-1119. DOI:

$1060 \quad$ 10.1603/ME11093.

1061 Li X, Cai JF, Guo YD, Wu KL, Wang JF, Liu QL, Wang XH, Chang YF, Yang L, Lan LM, 1062 Zhong M, Wang X, Song C, Liu Y, Li JB, Dai ZH. 2010. The availability of 16S rRNA for the identification of forensically important flies (Diptera: Muscidae) in China.

1065

1066

1067

1068

1069

1070

1071

1072

1073

1074

1075

1076

1077

1078

1079

1080 Tropical Biomedicine 27:155-166.

Lohr D. 2011. Casey Anthony Trial: The Battle Of The Bug Experts: The Huffington Post. Available at http://www.huffingtonpost.com/2011/06/17/casey-anthony-trial-bugexperts_n 879567.html (accessed 23 March 2017).

Lyra ML, Fresia P, Gama S, Cristina J, Klaczko LB, Lima De Azeredo-Espin AM. 2005. Analysis of mitochondrial DNA variability and genetic structure in populations of new world screwworm flies (Diptera: Calliphoridae) from Uruguay. Journal of Medical Entomology 42:589-595. DOI: 10.1093/jmedent/42.4.589.

MacLeod J, Donnelly J. 1957a. Individual and group marking methods for fly-population studies. Bulletin of Entomological Research 48:585-592. DOI: $10.1017 / \mathrm{S} 0007485300002753$.

MacLeod J, Donnelly J. 1957b. Some ecological relationships of natural populations of Calliphorine blowflies. Journal of Animal Ecology 26:135-170. DOI: 10.2307/1786.

MacLeod J, Donnelly J. 1960. Natural features and blowfly movement. Journal of Animal Ecology 29:85-93. DOI: 10.2307/2272.

MacLeod J, Donnelly J. 1962. Microgeographic aggregations in blowfly populations. Journal of Animal Ecology 31:525-543. DOI: 10.2307/2052. 
1081 Madra A, Konwerski S, Matuszewski S. 2014. Necrophilous Staphylininae (Coleoptera:

1082

1083

1084

1085

1086

1087

1088

1089

1090

1091

1092

1093

1094

1095

1096

1097

1098

1099

1100

1101 Staphylinidae) as indicators of season of death and corpse relocation. Forensic Science International 242:32-37. DOI: 10.1016/j.forsciint.2014.06.011.

Mann RW, Bass WM, Meadows L. 1990. Time since death and decomposition of the human body: variables and observations in case and experimental field studies. Journal of Forensic Sciences 35:103-111. DOI: 10.1520/JFS12806J.

Marchetti D, Arena E, Boschi I, Vanin S. 2013. Human DNA extraction from empty puparia. Forensic Science International 229:e26-e29. DOI: 10.1016/j.forsciint.2013.03.043.

Mariani R, García-Mancuso R, Varela GL, Inda AM. 2014. Entomofauna of a buried body: study of the exhumation of a human cadaver in Buenos Aires, Argentina. Forensic Science International 237:19-26. DOI: 10.1016/j.forsciint.2013.12.029.

Marquez JG, Krafsur ES. 2003. Mitochondrial diversity evaluated by the single strand conformation polymorphism method in African and North American house flies (Musca domestica L.). Insect Molecular Biology 12:99-106. DOI: 10.1046/j.13652583.2003.00391.x.

Martinez-Sanchez A, Marcos-Garcia M, Rojo S. 2001. First collection of Chrysomya megacephala (Fabr.) in Europe (Diptera: Calliphoridae). The Pan-Pacific Entomologist $77: 240-243$.

Martinez-Sanchez A, Rojo S, Marcos-Garcia MA. 2000. Annual and spatial activity of dung flies and carrion in a Mediterranean holm-oak pasture ecosystem. Medical and Veterinary Entomology 14:56-63. DOI: 10.1046/j.1365-2915.2000.00205.x. 
1102 Martin-Vega D, Gomez-Gomez A, Baz A. 2011. The "coffin fly" Conicera tibialis (Diptera:

1103 Phoridae) breeding on buried human remains after a postmortem interval of 18 years. $1104 \quad$ Journal of Forensic Sciences 56:1654-1656. DOI: 10.1111/j.1556-4029.2011.01839.x.

1105 Mason CF. 2002. Biology of freshwater pollution. New York, NY: Prentice Hall.

1106 Matuszewski S, Bajerlein D, Konwerski S, Szpila K. 2010. Insect succession and carrion

1107 decomposition in selected forests of Central Europe. Part 2: composition and residency

1108 patterns of carrion fauna. Forensic Science International 195:42-51. DOI:

$1109 \quad$ 10.1016/j.forsciint.2009.11.007.

1110 Matuszewski S, Szafałowicz M, Jarmusz M. 2013. Insects colonising carcasses in open and 1111 forest habitats of Central Europe: search for indicators of corpse relocation. Forensic

1112 Science International 231:234-239. DOI: 10.1016/j.forsciint.2013.05.018.

1113 Mazzanti M, Alessandrini F, Tagliabracci A, Wells JD, Campobasso CP. 2010. DNA

1114 degradation and genetic analysis of empty puparia: genetic identification limits in 1115 forensic entomology. Forensic Science International 195:99-102. DOI: 10.1016/j.forsciint.2009.11.022.

1117 Meiklejohn KA, Wallman JF, Dowton M. 2013. DNA barcoding identifies all immature life 1118 stages of a forensically important flesh fly (Diptera: Sarcophagidae). Journal of Forensic $1119 \quad$ Sciences 58:184-187. DOI: 10.1111/j.1556-4029.2012.02220.x.

1120 Merritt R, Wallace J. 2001. The role of aquatic insects in forensic investigations. In: Byrd JH, 1121 and Castner JL, eds. Forensic entomology: the utility of arthropods in legal 1122 investigations. Boca Raton, FL: CRC Press, 177-222. 
1123 Merritt RW, Snider R, de Jong JL, Benbow ME, Kimbirauskas RK, Kolar RE. 2007. Collembola

1124 of the grave: a cold case history involving arthropods 28 years after death. Journal of

1125 Forensic Sciences 52:1359-1361. DOI: 10.1111/j.1556-4029.2007.00568.x.

1126 Miller Coyle H, Lee CL, Lin WY, Lee HC, Palmbach TM. 2005. Forensic botany: using plant

1127 evidence to aid in forensic death investigation. Croatian Medical Journal 46:606-612.

1128 Mozayani A, Noziglia C. 2011. The forensic laboratory handbook procedures and practice.

1129 Totowa, NJ: Humana Press.

1130 Nazni WA, Luke H, Wan Rozita WM, Abdullah AG, Sa'diyah I, Azahari AH, Zamree I, Tan SB,

1131 Lee HL, Sofian MA. 2005. Determination of the flight range and dispersal of the house

1132 fly, Musca domestica (L.) using mark release recapture technique. Tropical Biomedicine

$1133 \quad 22: 53-61$.

1134 Njau DG, Muge EK, Kinyanjui PW, Omwandho COA, Mukwana S. 2016. STR analysis of

1135 human DNA from maggots fed on decomposing bodies: assessment of the time period for

1136 successful analysis. Egyptian Journal of Forensic Sciences 6:261-269. DOI:

$1137 \quad$ 10.1016/j.ejfs.2015.04.002.

1138 Nuorteva P. 1963. Synanthropy of blow flies (Diptera, Calliphoridae) in Finland. Annales

$1139 \quad$ Entomologica Fennica 29:1-49.

1140 Nuorteva P. 1964. Differences in the ecology of L. caesar (L.) and L. illustris (Meig.) (Diptera,

1141 Callphoridae) in Finland. Wiadomosci Parazytologiczne 10:583-587.

1142 O’Brien A, Townsend K, Hale R, Sharley D, Pettigrove V. 2016. How is ecosystem health

1143 defined and measured? A critical review of freshwater and estuarine studies. Ecological

1144 Indicators 69:722-729. DOI: 10.1016/j.ecolind.2016.05.004. 
1145 Ody H, Bulling MT, Barnes KM. 2017. Effects of environmental temperature on oviposition

1146 behavior in three blow fly species of forensic importance. Forensic Science International

$1147 \quad$ 275:138-143. DOI: 10.1016/j.forsciint.2017.03.001.

1148 Ogden R, Linacre A. 2015. Wildlife forensic science: a review of genetic geographic origin

1149 assignment. Forensic Science International. Genetics 18:152-159. DOI:

$1150 \quad$ 10.1016/j.fsigen.2015.02.008.

1151 Park SH, Park CH, Zhang Y, Piao H, Chung U, Kim SY, Ko KS, Yi C-H, Jo T-H, Hwang J-J.

1152 2013. Using the developmental gene bicoid to identify species of forensically important

1153 blowflies (Diptera: Calliphoridae). BioMed Research International 2013:538051. DOI:

$1154 \quad 10.1155 / 2013 / 538051$.

1155 Parry NJ, Mansell MW, Weldon CW. 2016. Seasonal, locality, and habitat variation in

1156 assemblages of carrion-associated Diptera in Gauteng Province, South Africa. Journal of

1157 Medical Entomology 53:1322-1329. DOI: 10.1093/jme/tjw104.

1158 Payne JA, King EW, Beinhart G. 1968. Arthropod succession and decomposition of buried pigs.

1159 Nature 219:1180-1181. DOI: 10.1038/2191180a0.

1160 Payne-James J, Byard R. 2015. Encyclopedia of forensic and legal medicine.Vol. 1-4. $1161 \quad$ Amsterdam: Elsevier Science.

1162 Pechal JL, Moore H, Drijfhout F, Benbow ME. 2014. Hydrocarbon profiles throughout adult 1163 Calliphoridae aging: a promising tool for forensic entomology. Forensic Science 1164 International 245:65-71. DOI: 10.1016/j.forsciint.2014.10.01.

1165 Perotti MA, Lee Goff M, Baker AS, Turner BD, Braig HR. 2009. Forensic acarology: an 1166 introduction. Experimental \& Applied Acarology 49:3-13. DOI: 10.1007/s10493-009$1167 \quad 9285-8$. 
1168 Picard CJ, Villet MH, Wells JD. 2012. Amplified fragment length polymorphism confirms

1169 reciprocal monophyly in Chrysomya putoria and Chrysomya chloropyga: a correction of

1170 reported shared mtDNA haplotypes. Medical and Veterinary Entomology 26:116-119.

$1171 \quad$ DOI: $10.1111 / \mathrm{j} .1365-2915.2011 .00976 . x$.

1172 Picard CJ, Wells JD. 2009. Survey of the genetic diversity of Phormia regina (Diptera:

1173 Calliphoridae) using amplified fragment length polymorphisms. Journal of Medical

$1174 \quad$ Entomology 46:664-670. DOI: 10.1603/033.046.0334.

1175 Picard CJ, Wells JD. 2010. The population genetic structure of North American Lucilia sericata

1176 (Diptera: Calliphoridae), and the utility of genetic assignment methods for reconstruction

1177 of postmortem corpse relocation. Forensic Science International 195:63-67. DOI:

$1178 \quad$ 10.1016/j.forsciint.2009.11.012.

1179 Pilli E, Agostino A, Vergani D, Salata E, Ciuna I, Berti A, Caramelli D, Lambiase S. 2016.

1180 Human identification by lice: a next generation sequencing challenge. Forensic Science

1181 International 266:e71-e78. DOI: 10.1016/j.forsciint.2016.05.006.

1182 Pohjoismaki JL, Karhunen PJ, Goebeler S, Saukko P, Saaksjarvi IE. 2010. Indoors forensic

1183 entomology: colonization of human remains in closed environments by specific species

1184 of sarcosaprophagous flies. Forensic Science International 199:38-42. DOI:

$1185 \quad$ 10.1016/j.forsciint.2010.02.033.

1186 Povolny D. 1971. Synanthropy. definition, evolution and classification. In: Greenberg B, ed.

$1187 \quad$ Flies and disease: ecology, classification, and biotic associations. Princeton, NJ:

1188 Princeton University Press, 17-54. 
1189 Reibe S, Madea B. 2010. How promptly do blowflies colonise fresh carcasses? A study

$1190 \quad$ comparing indoor with outdoor locations. Forensic Science International 195:52-57.

1191 DOI: 10.1016/j.forsciint.2009.11.009.

1192 Reibe S, Strehler M, Mayer F, Althaus L, Madea B, Benecke M. 2008. Dumping of corpses in 1193 compost bins-two forensic entomological case reports. Archiv fur Kriminologie 222:1951194201.

1195 Reigada C, Giao JZ, Galindo LA, Godoy WA. 2011. Survival of submerged blowfly species and 1196 their parasitoids: implications for postmortem submersion interval. Forensic Science 1197 International 212:126-129. DOI: 10.1016/j.forsciint.2011.06.002.

1198 Rognes K. 1991. Blow flies (Diptera, Calliphoridae) of Fennoscandia and Denmark. Leiden: EJ: 1199 Brill/Scandinavian Science Press.

1200 Rosenbaum F, Devigne C, Charabidzé D. 2016. Ecologie des Dermestidae, une famille de 1201 Coléoptères nécrophages associée aux cadavres squelettisés. Annales de la Société 1202 Entomologique de France (N.S.) 51:294-302. DOI: 10.1080/00379271.2015.1096751.

1203 Schumann H. 1990. Über das vorkommen von Dipteren in wohnräumen. Angewandte $1204 \quad$ Parasitologie 31:131-141.

1205 Simmons T, Cross PA, Adlam RE, Moffatt C. 2010. The influence of insects on decomposition 1206 rate in buried and surface remains. Journal of Forensic Sciences 55:889-892. DOI: 10.1111/j.1556-4029.2010.01402.x.

1208 Smith KE, Wall R. 1997. The use of carrion as breeding sites by the blowfly Lucilia sericata and 1209 other Calliphoridae. Medical and Veterinary Entomology 11:38-44. DOI: 10.1111/j.1365$1210 \quad$ 2915.1997.tb00287.x. 
1211 Smith KGV. 1986. A manual of forensic entomology. London: Trustees of the British Museum 1212 (Natural History).

1213 Sonet G, Jordaens K, Braet Y, Bourguignon L, Dupont E, Backeljau T, De Meyer M, Desmyter

1214

1215

1216

1217

1218

1219

1220

1221

1222

1223

1224

1225

1226

1227

1228

1229

1230

1231

1232
S. 2013. Utility of GenBank and the barcode of life data systems (BOLD) for the identification of forensically important Diptera from Belgium and France. ZooKeys 307328. DOI: $10.3897 /$ zookeys.365.6027.

Sorg MH, Dearborn JH, Monahan EI, Ryan HF, Sweeney KG, David E. 1996. Forensic taphonomy in marine contexts. In: Haglund WD, and Sorg MH, eds. Forensic taphonomy: the postmortem fate of human remains. Boca Raton, FL: CRC Press, 567604.

Sperling FA, Anderson GS, Hickey DA. 1994. A DNA-based approach to the identification of insect species used for postmortem interval estimation. Journal of Forensic Sciences 39:418-427. DOI: 10.1520/JFS13613J..

Starkeby M. 2001. Dead larvae of Cynomya mortuorum (L.) (Diptera, Calliphoridae) as indicators of the post-mortem interval-a case history from Norway. Forensic Science International 120:77-78. DOI: 10.1016/S0379-0738(01)00430-3.

Syamsa RA, Omar B, Ahmad FMS, Hidayatulfathi O, Shahrom AW. 2017. Comparative fly species composition on indoor and outdoor forensic cases in Malaysia. Journal of Forensic and Legal Medicine 45:41-6.

Szpila K, Pape T, Hall MJ, Madra A. 2014. Morphology and identification of first instars of European and Mediterranean blowflies of forensic importance. Part III: Calliphorinae. Medical and Veterinary Entomology 28:133-142. DOI: 10.1111/mve.12021. 
1233 Szpila K, Voss JG, Pape T. 2010. A new dipteran forensic indicator in buried bodies. Medical 1234 and Veterinary Entomology 24:278-283. DOI: 10.1111/j.1365-2915.2010.00883.x.

1235 Szyniszewska AM, Tatem AJ. 2014. Global assessment of seasonal potential distribution of 1236 Mediterranean fruit fly, Ceratitis capitata (Diptera: Tephritidae). PLoS One 9:e111582. DOI: 10.1371/journal.pone.0111582.

1238 Tomberlin JK, Adler PH. 1998. Seasonal colonization and decomposition of rat carrion in water 1239 and on land in an open field in South Carolina. Journal of Medical Entomology 35:704709. DOI: $10.1093 /$ jmedent/35.5.704.

1242

Tomberlin JK, Mohr R, Benbow ME, Tarone AM, VanLaerhoven S. 2011. A roadmap for bridging basic and applied research in forensic entomology. Annual Review of Entomology 56:401-421. DOI: 10.1146/annurev-ento-051710-103143.

Van Laerhoven SL, Anderson GS. 1999. Insect succession on buried carrion in two biogeoclimatic zones of British Columbia. Journal of Forensic Sciences 44:32-43.

Vanin S, Tasinato P, Ducolin G, Terranova C, Zancaner S, Montisci M, Ferrara SD, Turchetto M. 2008. Use of Lucilia species for forensic investigations in Southern Europe. Forensic Science International 177:37-41. DOI: 10.1016/j.forsciint.2007.10.006.

Voss SC, Spafford H, Dadour IR. 2009. Annual and seasonal patterns of insect succession on Italy including the blowfly Calliphora loewi (Diptera, Calliphoridae), a new species of forensic interest. Forensic Science International 207:e30-e33. DOI: decomposing remains at two locations in Western Australia. Forensic Science International 193:26-36. DOI: 10.1016/j.forsciint.2009.08.014. 
1256 Wang X, Cai J, Guo Y, Chang Y, Wu K, Liu Q, Wang J, Li Y, Lan L, Zhong M, Wang X, Cheng 1257 YS. 2010. The availability of 16SrDNA gene for identifying forensically important

1258

1259

1260

1261

1262

1263

1264

1265

1266

1267

1268

1269

1270

1271

1272

1273

1274

1275

1276

1277

1278

blowflies in China. Romanian Journal of Legal Medicine 18:43-50. DOI:

10.4323/rjlm.2010.43.

Wells JD, Introna F Jr, Di Vella G, Campobasso CP, Hayes J, Sperling FA. 2001. Human and insect mitochondrial DNA analysis from maggots. Journal of Forensic Sciences 46:685687. DOI: 10.1520/JFS15022J.

Wells JD, Sperling FAH. 2001. DNA-based identification of forensically important Chrysomyinae (Diptera: Calliphoridae). Forensic Science International 120:110-115. DOI: $10.1016 / \mathrm{S} 0379-0738(01) 00414-5$.

Wells JD, Stevens JR. 2010. Molecular methods for forensic entomology. In: Byrd JH, and Castner JL, eds. Forensic entomology: the utility of arthropods in legal investigations. 2nd ed. Boca Raton, FL: CRC Press, 437-452.

Wilby RL. 2003. Past and projected trends in London's urban heat island. Weather 58:251-260. DOI: 10.1256/wea.183.02.

Wooldridge J, Scrase L, Wall R. 2007. Flight activity of the blowflies, Calliphora vomitoria and Lucilia sericata, in the dark. Forensic Science International 172:94-97. DOI: 10.1016/j.forsciint.2006.12.011.

Wyss C, Cherix D, Mangin P. 2013. Traité d'entomologie forensique : les insectes sur la scène de crime. Paris: PPUR Presses Polytechniques.

Zabala J, Díaz B, Saloña-Bordas MI. 2014. Seasonal blowfly distribution and abundance in fragmented landscapes. Is it useful in forensic inference about where a corpse has been decaying? PLoS One 9:e99668. DOI: 10.1371/journal.pone.0099668. 